\title{
Sınıf Öğretmenlerinin Mesleki Görevlerine Yönelik Ders Dışı Zaman Kullanımları ${ }^{1}$
}

\section{Determination of Classroom Teachers' Extra-Curricular Time Use for Professional Tasks}

Cennet Göloğlu Demir, Milli Eğitim Bakanlığı Karabük Bilim ve Sanat Merkezi, gologlu.cennet@gmail.com Yücel Gelişli, Gazi Eğitim Fakültesi Eğitim Bilimleri Bölümü, gelisli@gazi.edu.tr

\begin{abstract}
ÖZ. Bu araştırmanın amacı sınıf öğretmenlerinin mesleki görevlerine yönelik ders dışı zaman kullanımlarının belirlenmesidir. Araştırma tarama modelinde olup araştırma sürecinde nicel araştırma yöntemleri kullanılmıștır. Araştırma verilerini toplamak amacıyla iki bölümden oluşan anket hazırlanmıștır. Anketin I. bölümünü "Öğretmenlerin Demografik Özellikleri", II. bölümünü araştırmacı tarafından geliştirilen "Mesleki Görevlere Yönelik Zaman Kullanımı Ölçeği”" olușturmaktadır. Araștırmanın çalışma evrenini Karabük İlindeki devlet ilkokullarında çalışan 517 sınıf öğretmeni oluşturmaktadır. Nicel verilerin toplanmasında evrenin tamamına ulaşılması düşünüldüğünden örneklem alınmamıştır. 414 anket ile asıl uygulama analizleri yapılmıştır. Araştırmanın sonuçları şu şekildedir: Öğretmenlerin mesleki görevlerine yönelik "Genel Zaman Kullanımı" orta düzeydedir. Öğretmenler mesleki görevlerine yönelik en fazla zamanı: "öğretme ve öğretime hazırlık" görevi için en az zamanı ise "sosyal etkinlikler ve rehberlik" görevi için harcamaktadırlar. Öğretmenler mesleki faaliyetler arasında en az zamanı "öğrenci kulübü ve toplum hizmetine ilişkin çalışmalara (hazırlıklar, faaliyetleri yapma vb.)" en fazla zamanı ise "materyal ve etkinlik kağıtlarını hazırlama, çoğaltma vb. hazırlıklar (BEP olan öğrenciler için yapılan hazırlıklar dahil)" için ayırmaktadır.
\end{abstract}

Anahtar Sözcükler: Öğretmenlerin Mesleki Görevleri, Öğretmenlerin Mesleki Faaliyetleri, Zaman

\begin{abstract}
The purpose of this study is to determine the classroom teachers' extra-curricular time use for professional tasks. This research is a survey model and quantitative research methods were used in the research process. In order to collect research data, a questionnaire consisting of two parts was prepared. The first part of the questionnaire is "Demographic Characteristics of Teachers" and the second part of the questionnaire is the "Teachers' Extra-Curricular Time Use Scale for Professional Tasks " developed by the researcher. The population of the study consists of 517 classroom teachers working in state primary schools in Karabuk city. No sampling procedure is applied as we consider to reach all participants while collecting the quantitative data. 414 questionnaires were used to analyze the main implementation. The results of the study reveal that the teachers' extra-curricular time use for professional tasks is medium level. Teachers spend most of their time to "get prepared for teaching and instruction", and for the task of "social activities and coaching" at least. Teachers spend least of their time "student clubs and community service" (preparations, doing activities etc.) and most of their time "preparation and copying of material and activity papers (including the preparations for the children with special needs)".
\end{abstract}

Keywords. Teachers' Professional Tasks, Teachers' Professional Activities, Time

\section{SUMMARY}

Purpose and Significance: Teachers have a variety of professional tasks apart from the subject area teaching. For this reason, teachers' working hours are not limited to the school time. Teachers work both within the school time and post-school time for the sake of tasks. During the school hours teachers perform professional tasks on breaks, lunchtime and relaxation time etc. Out of school time, teachers spare time for their professional tasks in evenings and weekends. Hence, teachers' extracurricular time use for professional tasks become important. As a result the purpose of this study is to determine the classroom teachers' extra-curricular time use for professional tasks.

Methodology: This research is a survey model and quantitative research methods were used in the research process. In order to collect research data, a questionnaire consisting of two parts was prepared. The first part of the questionnaire is "Demographic Characteristics of Teachers" and the second part of the questionnaire is the "Teachers' Extra-Curricular Time Use Scale for Professional Tasks " developed by the researcher. The population of the study consists of 517 classroom teachers working in state primary schools in Karabuk city. No sampling procedure is applied as we consider 
to reach all participants while collecting the quantitative data. The quantitative data was gathered through 414 teachers.

Results: The results of the study reveal that the teachers' extra-curricular time use for professional tasks is medium level. Teachers spend most of their time to "get prepared for teaching and instruction", and "social activities and coaching" at least. Teachers spend least of their time "student clubs and community service" (preparations, doing activities etc.) and most of their time "preparation and copying of material and activity papers (including the preparations for the children with special needs)". Female teachers spend more time on their professional duties than male teachers. Teachers with a five year experience spend more time on "preparation for teaching and instructions" duty and "Professional development" compared to more experienced ones. Teachers who teach 1-10 students spend less time on professional duties than the ones teaching more students. Teachers who graduated from institutions apart from faculty of education spend less time on "assessment and evaluation", "professional development", "social activities and coaching" and "board, commission and meetings" compared to the ones who graduate from other institutions.

Discussion and Conclusion: The results of the study reveal that the teachers' extra-curricular time use for professional tasks is not high. Due to the fact that time using become different according to varies of variables, When make school schedule is considered not only the needs of the student and subject area but also teachers needs.

\section{GíRIș}

Zaman, bütün bireyler için eşit olan ve kişiye göre anlam kazanan önemli bir kaynaktır. Dolayısıyla bireylerin bu kaynağı en verimli şekilde harcaması önemlidir. Bireyler bu kaynağın önemli bir kısmını da meslekleri için harcamaktadır. Öğretmenlik mesleği için zaman kullanımı ele alındığında, öğretmenlerin zamanlarının önemli bir kısmını öğretimle geçirdiği düşünülebilir. Bununla birlikte öğretmenlerin öğretim dıșında yaptıkları birçok faaliyet bulunmaktadır. Öğretmenlerin başta öğretim olmak üzere bütün faaliyetlerini etkili bir şekilde yürütmesi beklenmektedir. Eğitim ve öğretimin etkili olabilmesi, öğretmenlerin kendilerinden yapmaları beklenen faaliyete gerektiği önemi vermesi ve yeteri kadar zamanı ayırması ile mümkün olacaktır.

Jha, Minni ve Ghata (2016) öğretmenlerin görevlerini, okul içinde (öğretimle ilişkili ve öğretimle doğrudan ilişkili olmayan) ve okul dışında (eğitimsel amaçlı ve doğrudan eğitimsel amacı olmayan) şeklinde sınıflamaktadır. Öğretmen görevlerinin okul içinde ve okul dişında olması öğretmenlerin çalışma sürelerinin de okulla sınırlı kalmaması anlamına gelmektedir. Öğretmenler işleri gereği hem okul saatleri içerisinde hem de okul saatleri dişında çalışmaktadır. Bununla ilgili olarak Campbell ve Neil (1994a)'de öğretmen açısından zamanı Şekil 1'deki gibi analiz etmektedir: 


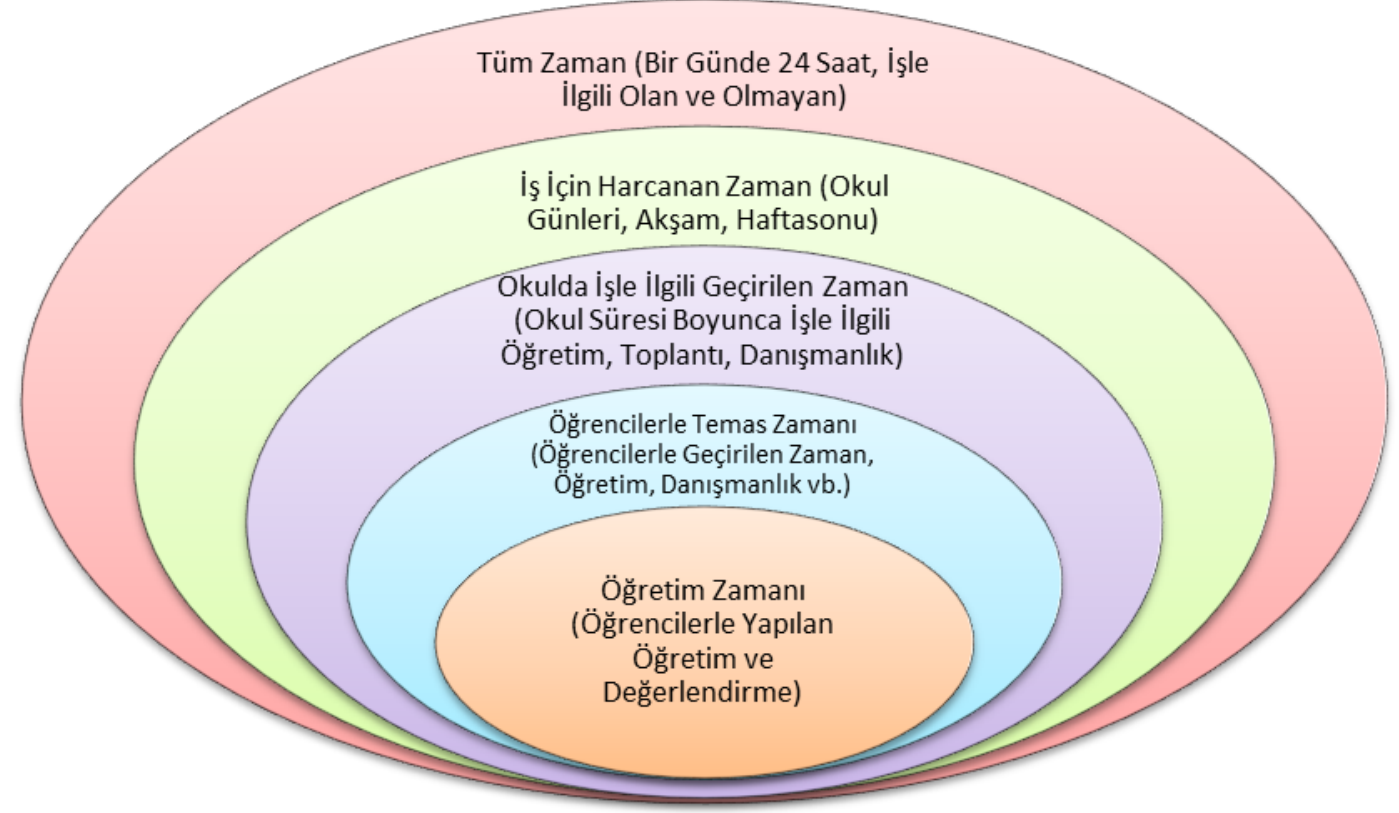

Şekil 1. Öğretmenin zamanı. Kaynak: Campbell, R. J., \& Neill, S. R. St. J. (1994a). Primary teachers at work. New York, NY: Routledge.

Şekil 1 incelendiğinde öğretmenlerin zamanlarının farklı şekilde kategorize edilebileceği görülmektedir. Okulda ve okul dışında meslekleriyle ilgili faaliyetler için harcanan zaman; okul içeresindeki öğretim ve öğretim dışı zaman; öğrencilerle iletişim içerisinde olunan ve olunmayan zaman şeklinde de düşünülebilir. Hilsum ve Cane (1971), öğretmenlerin işleriyle ilgili olarak çalıştıkları toplam sürenin yaklaşık \%60'ını doğrudan sınıflarında, \%15' ini okulda fakat sınıf dışında, \%25'ini ise tümüyle okul saatleri dışında harcadıklarını ortaya koymaktadır. Garrick ve diğerleri (2017) öğretmenlerin evlerinde ortalama günde iki saat 15 dakika işle ilgili aktivitelere zaman ayırdıklarını ve bu zamanın öğretmenlerin kronik yorgunluğunu yüksek düzeyde etkilediği sonucuna ulaşmışlardır. Higton ve diğerleri (2017) tarafından sınıf öğretmenlerinin çalışma saatlerinin çok fazla olduğu, hafta da ortalama 18.8 saat okul dışında çalıştıkları belirtilmiştir. Öğretmenlerin bu çalışma saatlerinden memnun olmadıkları da araştırma sonuçları arasındadır.

Wolf (2002) ise zamanla birlikte öğretmenlerin faaliyetlerini de incelediği araştırmasında; öğretmenlerin işlerinin oldukça kapsamlı olduğunu, öncelikli işlerinin öğretim olmasına rağmen bunun dışında birçok sorumlulukları olduğunu belirtmiştir. Aynı araştırmacı Amerika Birleşik Devletleri'nde yaptı̆̆ çalışmanın sonucunda da öğretmenlerin, işlerinin \%20'sini evlerinde tamamladıklarını ve toplam zamanlarının \%40’ından daha azını gerçek öğretimle ilgili işlere harcadıklarını ortaya koymuştur. Gibson Oliver ve Dennison (2015) araştırmalarında ise öğretmenlerin \%82'si, not verme işlerindeki ayrıntılar, bürokratik işlemler, toplantı sayılarının fazlalığı, fotokopi vd. çoğaltma işlemleri gibi faaliyetlerin gereksiz ve verimsiz olduğunu düşünmektedir. Nitekim Öğretmenlerin belirttiği bu faaliyetlerde daha çok ders planlama, değerlendirme ve yönetime raporlamayla ilgilidir. Dolayısıyla öğretmenlerin öğretim süreleri kadar, meslekleriyle ilişkili diğer faaliyetler: veli görüşmeleri, toplantılar, sınav kağıtlarını okuma, plan yapma vb., için de ayırdıkları sürelerin araştırılması önem arz etmektedir. Ülkemizde ise öğretmenlerin görevlerine yönelik zaman kullanımı konusunda 1992-1993 eğitim-öğretim yılında Eğitimi Araştırma ve Geliştirme Dairesi Başkanlığı [EARGED] tarafından ortaöğretim kademesinde bir araştırma yapılmıştır. Araştırma sonuçları öğretmenlerin; bir haftada ders dışında eğitimöğretim-yönetim etkinlikleri için harcadıkları sürenin ortalama 23 saat olduğu ve bir haftada ders dışında en çok nöbet için daha sonra ders hazırlığı için zaman harcandığını göstermiştir. Araştırmada öğretmenlerin, sınıf öğretmenliği, eğitsel kol çalışmaları, veliler ve çevre ile ilişkiler, ödev danışmanlığı, meslekî gelişmeleri izleme gibi etkinlikler için ayırdıkları sürelerin 1-2 saat ile sınırlı kaldığını ortaya koymaktadır. Veriler, öğretmenlerin dönemlik faaliyetler açısından en çok sınav 
kağıdı değerlendirme ve sınav hazırlamaya, daha sonra sırası ile toplantılara, törenlere, ödev düzeltme ve sınav gözcülügüne zaman harcadıklarını göstermektedir. Benzer șekilde EARGED, 2011 yılı araştırma sonuçlarına göre öğretmenlerin bir hafta boyunca yaptıkları ders dışı etkinlikler ve bu etkinliklere ayırdıkları zaman (Abazaoğlu, Yıldırım \& Yıldızhan, 2014) şu şekildedir:

Öğretmenlerin \%51,2'si öğrencilere danışmanlık için ayırdıkları sürenin 1-2 saat olduğunu, \%40'ı haftalık velilerle görüşmeye ayırdıkları zamanın 1-2 saat olduğunu, \%42'si bir saatten az olduğunu belirtmektedir. Öğretmenlerin \%43,2'si sınav sorularını hazırlama ,\%41'i sınav sonuçlarını değerlendirmeye haftada 3-5 saat arasında zaman ayırdıklarını belirtmektedir. Öğretmenlerin \%12,1'i derse hazırlık yapma süresinin haftada beş saatten fazla olduğunu belirtmektedir. Öğretmenlerin \%42,3'ü meslekle ilgili yayınları okumaya 1-2 saat, \%33,2'si ise bir saatten daha az zaman ayırmaktadır. Öğretmenlerin \%42,5'i öğrenci kulüp etkinliklerine destek vermeye 1-2 saat, $\% 42,5$ 'i ise bir saatten daha az zaman ayırdığını belirtmektedir. Öğretmenlerin \%30,8'i 1-2 saat ve \%36,3'ü 3-5 saat internette araştırma yapmak için haftalık zaman ayırdığını belirtmektedir. Öğretmenlerin \% 39'u mesleki gelişim etkinliklerine bir saatten daha az, \%30,6'sı ise hiç zaman ayırmamaktadır.

İlgili kaynaklar (Avrupa Eğitim Bilgi Ağı, [Eurydice], 2008; Uluslararası Öğretme ve Öğrenme Araștırması, [TALIS], 2008) incelendiğinde öğretmenlerin mesleki görevleri ile mesleki görevlere ayırdıkları zamanın birlikte ele alınan iki temel konu olduğu görülmektedir. Örneğin, Avrupa ülkelerinde öğretmenlerin çalışma zamanının, iş sözleşmelerindeki tanımına bakıldığında, birçok ülkede çalışma zamanı, bir yanda dersler sırasındaki öğretim, diğer yanda derslerin hazırlanması ve değerlendirilmesini de içeren iki temel göreve ayrılan zaman olarak tanımlanmakla birlikte bazılarında çalışma zamanı ek görevleri de içermektedir (Eurydice, 2008). Örneğin; Finlandiya'da öğretmenlere, ders öncesi ve sonrası çalışmalar, plan yapma, okul gelişimi, paydaşlarla işbirliği gibi öğretim dışındaki görevler için temel eğitimde haftada üç saat, lise kademesinde ise iki haftada bir üç saat zaman ayrılmıştır Finnish National Board of Education, 2013). Bununla birlikte bazı ülkelerde, hizmet süresine göre öğretmenlerin öğretim görevine ayırdıkları sürenin azaltılması gibi uygulamalar yer almaktadır. Örneğin, Yunanistan'da 20 yll hizmet süresi olan bir öğretmen yeni başlayanlara göre \%25'in üzerinde daha az öğretim yapmaktadır. Ülkemizde ise benzer şekilde öğretmenlere girdikleri her 10 ders saati için; bir saat hazırlık ve planlama görevi için ek ders ücreti verilmektedir fakat okul saatleri içerisinde ayrı bir zaman verilmemektedir (http://ikgm.meb.gov.tr/tahakkuk/). Uluslararası Öğretme ve Öğrenme Araştırması'nda (TALIS, 2008) 23 ülkede çalışan öğretmenlerin görevleri ve bu görevlere ayırdıkları süreler incelenmiştir. Araştırmada öğretmenlerin görevleri "okulda öğretim", "ders planlama" ve "idari görevler" olmak üzere üç kategoriye ayrılmıştır. Bu görevlere ayrılan süreler ise hem deneyimli öğretmenler hem de yeni öğretmenler açısından incelenmiştir. Türkiye ortalaması ile TALIS ortalaması karşılaştırıldığında, Türkiye öğretim görevine harcanan süre bakımdan ortalamanın üzerinde iken, dersin planlanması ve idari görevlere ayrılan sürede ortalamanın altında kalmaktadır.

Öğretmenlerin mesleki görevleri, çalışma süreleri ve sorumlulukları; son yirmi yılda özellikle Avrupa ülkelerinde okula dayalı program geliştirme, okula dayalı yönetim ve mali özerklik gibi konularda kısaca okul özerkliği konusunda yaşanan gelişmelerle birlikte değişmektedir. Bu değişimleri daha çok öğretmenlerin program hazırlama sürecine etkin bir şekilde katılmasına izin verme, derse gelmeyen meslektaşlarının yerine derse girmeleri, yeni öğretmenleri yönlendirmeleri, ekip çalışmalarına katılmaları, okul gelişim planını hazırlama gibi konular oluşturmaktadır (Eurydice, 2008). Ülkemizde her ne kadar okul temelli bir program geliştirme süreci bulunmasa da, son yıllarda yaşanan gelişmelere paralel olarak öğretmenlerin okul gelişimine katılımları sağlanmaya çalışılmaktadır. Bu doğrultuda, okullarda "okul gelişim ve yönetim ekipleri" kurularak öğretmenlere, okulun fiziki şartlarının geliştirilmesi, sosyal etkinliklerin arttırılması vb. konularda çalışmaları için yeni görevler verilmektedir. Artan görevlerle birlikte öğretmenlerin meslekleriyle ilgili faaliyetler için harcadıkları zaman da değişmektedir. Ayrıca öğretmenlerin öğretimsel ve öğretimsel olmayan görevlere ayırdıkları zaman öğretmenlik mesleğinin cazibesini etkilerken, öğretmenlerin öğretim için harcadıkları sürenin miktarı da, ülkelerin eğitime ayırdıkları mali kaynakları etkilemektedir (OECD, 2012). Ayrıca öğretmenlerin iş yüklerinin (mesleki faaliyetleri) artması öğrencilerin akademik başarılarını da olumsuz yönde etkilemektedir (Gwambombo, 2013) Sonuç olarak öğretmenlerin konu alanı öğretimi dışındaki mesleki görevlerinin de ön plana çıktığı 
görülmektedir. Yapılan araştırmalar incelendiğinde ise ülkemizde sınıf öğretmenlerinin konu alanı öğretimi dışındaki mesleki görevlerine harcadıkları zamana bütünsel olarak yaklaşan bir çalışmaya rastlanmamıştır. Bu noktadan hareketle araştırmada "sınıf öğretmenlerinin mesleki görevlerine yönelik ders dışı zaman kullanımları ile bu görevlere yönelik görüşlerinin belirlenmesi" amaçlanmıştır. Bu doğrultuda aşağıdaki sorulara cevap aranmaya çalışılmıştır:

1) Sınıf öğretmenlerinin ders saatleri dışında;

- Öğretme ve Öğretime Hazırlık,

- Ölçme ve Değerlendirme,

- Mesleki Gelişim,

- Sosyal Etkinlikler ve Rehberlik

- Veli İşbirliği,

- Kurul, Komisyon ve Toplantılar,

- E-Okul İşlemleri ve diğer, mesleki görevlerine yönelik zaman kullanımları ne düzeydedir?

2. sınıf öğretmenlerinin ders saatleri dışındaki görevlerine yönelik zaman kullanımları arasinda;

- Cinsiyet,

- Kidem,

- Öğrenci sayısı,

- Okuttukları sinıf düzeyi

- Mezun oldukları kuruma göre anlamlı bir farklılık bulunmakta mıdır?

\section{YÖNTEM}

\section{Araștırma Deseni}

Araştırmada tarama modeli kullanılmıştır. Tarama modelleri, geçmişte ya da halen var olan bir durumu var olduğu şekliyle betimlemeyi amaçlayan araştırma yaklaşımlarıdır. Araştırmaya konu olan olay, birey ya da nesne, kendi koşulları içinde ve olduğu gibi tanımlanmaya çalışılır. Onları herhangi bir şekilde değiştirme, etkileme çabası gösterilmez. Bilinmek istenen şey vardır ve oradadır. Önemli olan, onu uygun bir biçimde gözleyip belirleyebilmektir (Karasar, 1998, s.77). Araştırmada nicel araştırma yöntemi kullanılmıştır.

\section{Evren ve Örneklem}

Araştırmanın çalışma evrenini Karabük ilindeki devlet ilkokullarında çalışan 517 sınıf öğretmeni oluşturmaktadır. Nicel verilerin toplanmasında evrenin tamamına ulașılması düşünüldüğünden örneklem alınmamıștır. Araştırma kapsamında 457 öğretmene yani çalışma evreninin yaklaşık \%88'ine ulaşılmıștır. Alınan anketlerden 43'ü tamamının yapılmaması, anketin tamamında tek bir şıkkın işaretlenmesi, çok fazla boş seçenek bırakılması vb. sebeplerden dolayı değerlendirme dışı bırakılmıştır. Geriye kalan 414 anket ile asıl uygulama analizleri yapılmıştır. Ögretmenlerin demografik özellikleri Tablo 1'de belirtilmiştir: 
Tablo 1. Çalışma Grubuna İlişkin Demografik Özellikler

\begin{tabular}{llll}
\hline & & Frekans & $\%$ \\
\hline Cinsiyet & Kadın & 226 & 54,6 \\
& Erkek & 188 & 45,4 \\
\hline Mesleki Deneyim & $1-5$ yll & 36 & 8,7 \\
& $6-10$ yıl & 69 & 16,7 \\
& $11-15$ yll & 76 & 18,4 \\
& $16-20$ yll & 85 & 20,5 \\
& 21 yıl ve üstü & 148 & 35,7 \\
\hline Öğrenci Sayısı & $1-10$ & 28 & 6,8 \\
& $11-20$ & 188 & 45,4 \\
& $21-30$ & 138 & 33,3 \\
& 31 ve üstü & 60 & 14,5 \\
\hline \multirow{5}{*}{ Sinıf Düzeyi } & $1 . s ı n ı f$ & 99 & 23,9 \\
& $2 . s i n f f$ & 98 & 23,7 \\
& $3 . s ı n ı f$ & 124 & 30,0 \\
\multirow{5}{*}{ Mezun Olunan Kurum } & 4. sinıf & 93 & 22,5 \\
& Eğitim Fakültesi & 230 & 55,6 \\
& Eğitim Önlisans & 79 & 19,1 \\
& Eğitim Enstitüsü & 34 & 8,2 \\
& Eğitim Fakültesi Dișı & 71 & 17,1 \\
\hline
\end{tabular}

\section{Veri Toplama Aracı}

Verilerin toplanması amacıyla iki bölümden oluşan anket hazırlanmıştır. Anketin birinci bölümünü öğretmenlerin, cinsiyet, kıdem, öğrenci sayısı, okuttukları sınıfın düzeyi ve mezun oldukları kuruma yönelik bilgilerinin alındığı "Öğretmenlerin Demografik Özellikleri", oluşturmaktadır. İkinci bölümünü ise araştırmacı tarafından geliştirilen "Mesleki Görevlere Yönelik Zaman Kullanımı" ölçeği oluşturmaktadır.

\section{Mesleki Görevlere Yönelik Zaman Kullanımı Öıçeği Maddelerinin Oluşturulması}

Mesleki görevlere yönelik zaman kullanımı ölçeği yurt içi ve yurt dışındaki alan yazın dikkate alınarak hazırlanmıştır. Ayrıca anket maddelerinin oluşumuna temel olması açısından konuyla ilgili 75 öğretmenden "Bir öğretmen olarak sizin eğitim-öğretimle ilgili ne tür görevleriniz bulunmaktadır? Ayrıntılı olarak açıklayınız." şeklindeki açık uçlu soruyu cevaplamaları istenmiştir. 75 öğretmenden 41'i geri dönmüştür. Kompozisyonların analiz sonucu ve literatüre dayalı olarak 11 kategori ve 54 maddeden oluşan bir madde havuzu oluşturulmuştur. Bu aşamayı takiben kapsam geçerliliği ve maddelerin bulundukları kategori ile uyumlu olup olmadığının tam olarak ortaya çıkarılması için beş akademisyen, altı öğretmen, üç idareci ve bir okul rehber öğretmeninin görüşleri alınmıştır. Alınan görüşler doğrultusunda öğretmenlerin görevlere yönelik faaliyetlerinin belirlenmesinde; "Öğretme ve Öğretime Hazırlık, Ölçme ve Değerlendirme, Mesleki Gelişim, Rehberlik, Veli İşbirliği, Sosyal Etkinlikler, Kurul, Komisyon ve Toplantılar, E-Okul, İdari İșler ve Diğer" görevleri dikkate alınmıştır ve bu görevlere uygun şekilde maddeler oluşturulmuştur. Ön uygulama ölçeği 39 madde ile sınırlandırılmıștır. Öğretmenlere "bir dönemde ders saatleriniz dışında belirtilen faaliyetlere ne kadar zaman ayırmaktasınız?" sorusu yöneltilmiştir. Mesleki görevlere yönelik zaman kullanımı ölçeğinin geliştirilmesinde izlenen aşamalar Şekil 2'de gösterilmiştir. 


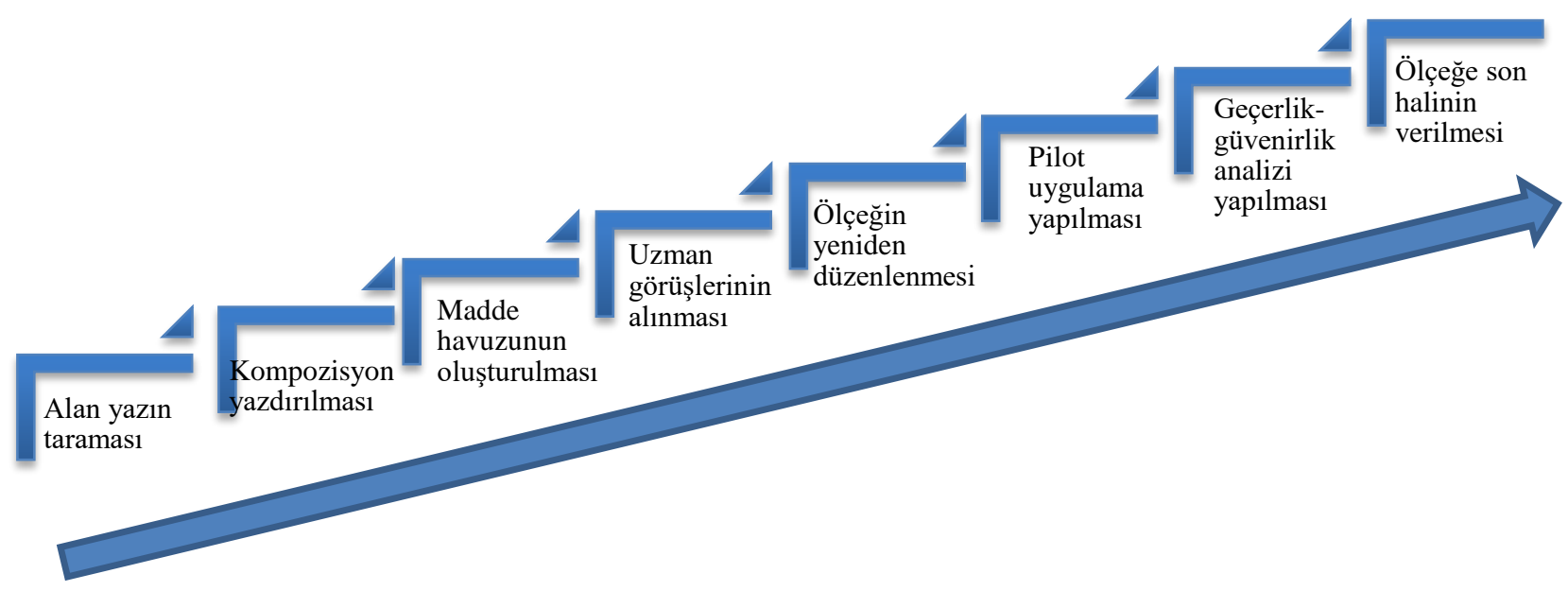

Şekil 2. Mesleki görevlere yönelik zaman kullanımı ölçeğinin geliştirilme aşamaları

\section{Mesleki Görevlere Yönelik Zaman Kullanımı Ölçeği Geçerlik- Güvenirlik Çalışması}

Mesleki görevlere yönelik zaman kullanımı ölçeğinin geliştirilmesi için 380 öğretmenle pilot uygulama yapılmıştır. Fakat kötü cevaplanmış, çok fazla boş bırakılmış veya bir kısmı cevaplanmamış anketler analiz edilmemiştir. Geriye kalan 337 anketten elde edilen verilerle analiz gerçekleştirilmiştir. Sınıf öğretmenlerinden elde edilen veriler "Hiç", "Az", "Orta”, "Fazla”, "Çok Fazla" seçenekleri 1, 2, 3, 4, 5 şeklinde puanlanarak SPSS programı aracılığıyla bilgisayar ortamına aktarılırmıştır.

Veri yığınının bilgisayar ortamına aktarılmasından sonra 39 maddeden oluşan ölçeğin faktör yapısı belirlenmeye çalışılmıştır. Bu belirleme işlemi Temel Bileşenler Analizi kullanılarak yapılmıştır. Kaiser-Meyer Olkin (KMO) örneklem iyiliği, 893 olarak bulunmuştur. Dolayısıyla faktör analizi yapabilmek için örneklem büyüklüğünün "çok iyi düzeyde" iyi olduğu değerlendirmesi yapılabilir (Hutcheson \& Sofroniou,1999, Akt: Field, 2009, s.640).

Ayrıca Bartlett küresellik testi sonuçları incelendiğinde elde edilen sonuçların anlamlı olduğu görülmüştür $(\chi 2(741)=7269,844, p<.01)$. Elde edilen sonuç değişkenler arasında yüksek korelasyonların bulunduğunu, başka bir deyişle veri setinin temel bileşenler analizi için uygun olduğunu göstermektedir (Kalaycı, 2006, s.327).

Yapılan faktör analizinde, faktör sayısına müdahale edilmeyerek faktörler serbest bırakılmıştır ve özdeğer istatistiği (eigenvalues) 1.00'den büyük olan faktörler anlamlı olarak kabul edilmiştir (Dunteman'dan(1989) aktaran Kalaycl, 2006, s.322).

Ölçeğin birbirinden bağımsız alt faktörlerini belirlemek için varimax dik döndürme yöntemi kullanılmıştır. Faktör yüklerinin alt kesme noktası olarak 0.45 değeri ölçüt olarak alınmıştır. İlk yapılan analizde ölçeğin sekiz faktörlü olduğu, 8., 20., 30. ve 31. maddelerinde faktör yüklerinin .45’ in altında olduğu tespit edilmiştir. Bu maddeler ölçekten çıkarıldıktan sonra tekrar analiz yapılmıştır.

İkinci analizde ölçeğin yedi faktörlü bir yapı oluşturduğu ve toplam varyansın \%63,40'ını açılkladığı tespit edilmiştir ve maddelerin faktör yüklerinin .49 ile .83 arasında olduğu görülmüştür. Faktör analizi sonucunda elde edilen 35 maddenin, öğretmenlerin görevlerine yönelik zaman kullanımları ölçeğinin hazırlanmasında gözetilen yedi yapıyı:

- $\quad$ Kurul, Komisyon ve Toplantılar,

- $\quad$ Öğretme ve Öğretime Hazırlık,

- $\quad$ Sosyal Etkinlikler ve Rehberlik,

- $\quad$ E-Okul İşlemleri ve Diğer,

- Mesleki Gelişim,

- $\quad$ Veli İşbirliği,

- $\quad$ Ölçme ve Değerlendirme, yansıttığı düşünülmektedir.

Ölçeğin güvenirliliğini belirlemek amacıyla Cronbach Alpha iç tutarlık katsayıları hesaplanmıştır. Ölçeğin iç tutarlık katsayısı (Cronbach Alpha) .93 olarak bulunmuştur. Alt faktörler 
de ise .75 ve üzerinde olduğu tespit edilmiștir. Bu bulgular Kalaycı (2006, s.405)'nın belirtmiş olduğu $0.60 \leq \alpha \leq 0.80$ ise ölçek oldukça güvenilir, $0.80 \leq \alpha \leq 1.00$ ise ölçek yüksek derecede güvenilir, șeklinde yorumlandığında sonuçlar ölçeğin oldukça güvenilir olduğunu göstermektedir.

Yedi faktörlü olduğu saptanan ölçeğin her bir alt faktör için madde toplam korelasyonları ise sırasıyla faktör bir için .623 ile .778; faktör iki için .551 ile.669, faktör üç için .593 ile .746, faktör dört için, .571 ile .630, faktör beş için .586 ile .678, faktör altı için .558 ile.708, faktör yedi için .461 ile .598 değiştiği görülmüştür. Kalaycı(2006, s.412-413)'ya göre madde-toplam korelasyonlarının negatif olmaması ve 0,25 değerinden büyük olması ölçeğin toplanabilirlik özelliğinin bozulmaması için yeterlidir. Ayrıca pilot uygulamada üst $\% 27$ ve alt $\% 27^{\prime}$ lik grupların her bir maddeye verdikleri cevaplar iliş̧isiz t testi ile karşılaştırılmıştır.

Ölçeğin maddeler çıkarıldıktan sonra elde edilen geçerlik ve güvenirlik analizi değerleri Tablo 2'de ayrıntılı olarak verilmiștir.

Tablo 2. Mesleki Görevlere Yönelik Zaman Kullanımı Ölçeği Geçerlik-Güvenirlik Analizi Değerleri

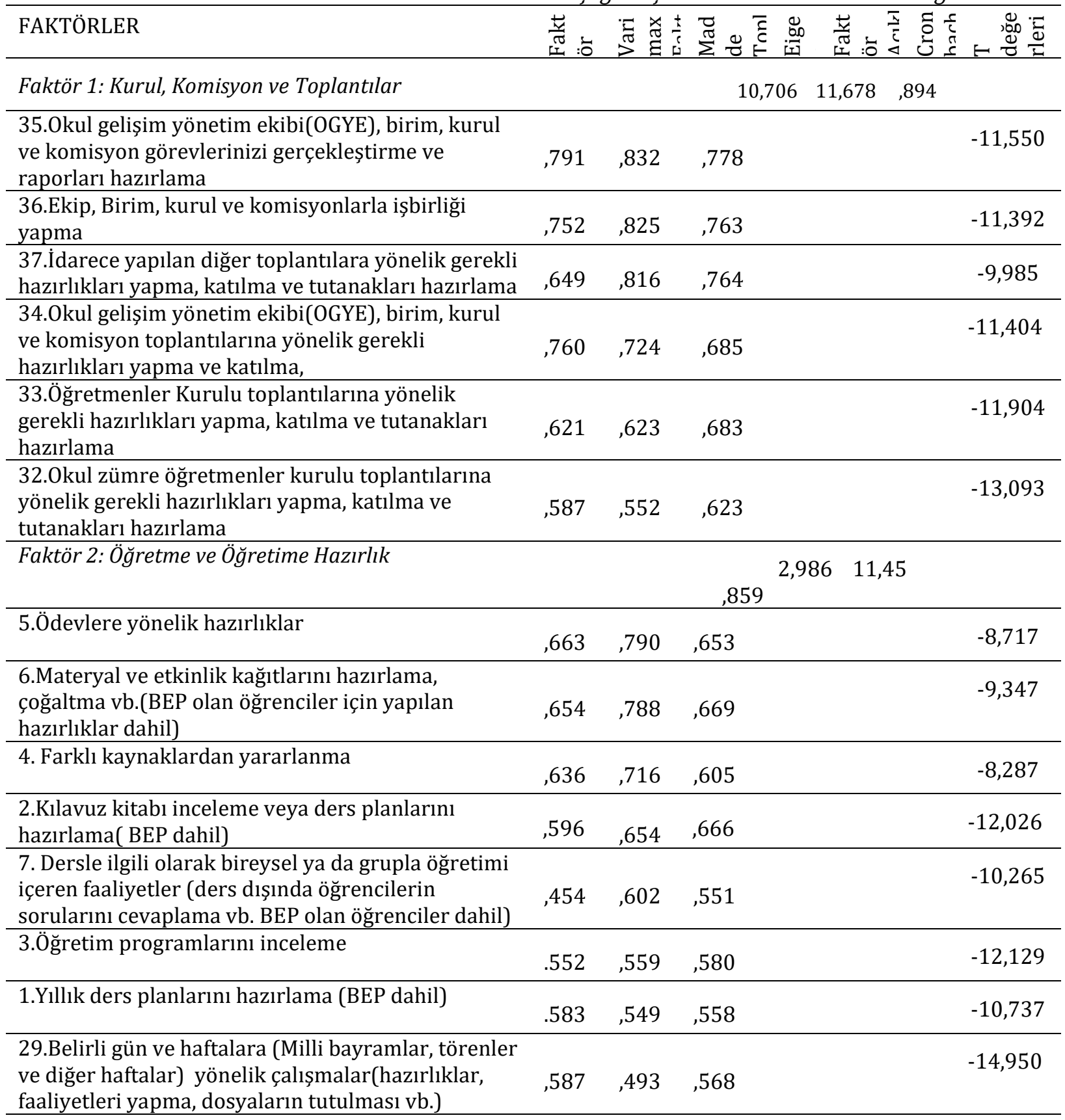




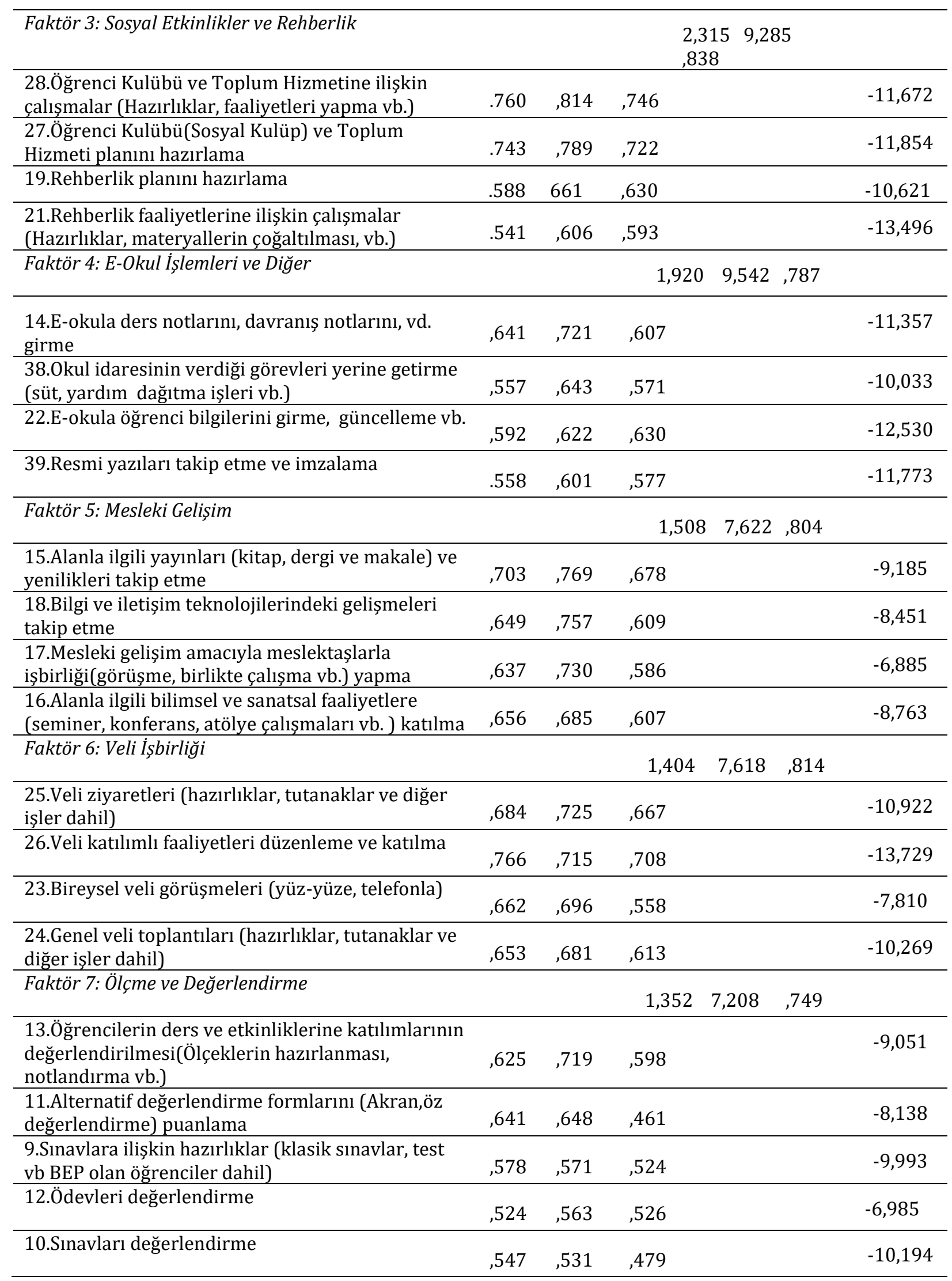

*Tüm "t" değerleri 0.001 düzeyinde anlamlıdır. 


\section{BULGULAR}

Bu bölümde elde edilen bulgular, araştırmanın alt problemleri doğrultusunda verilmiştir.

\section{Araştırmanın Birinci Alt Problemine İlişkin Bulgular}

$\mathrm{Bu}$ bölümde araştırmanın birinci alt problemi doğrultusunda, sınıf öğretmenlerinin ders saatleri dışında; "Öğretme ve Öğretime Hazırlık", "Ölçme ve Değerlendirme”, "Mesleki Gelişim", "Sosyal Etkinlikler ve Rehberlik", "Veli İșbirliği" , "Kurul, Komisyon ve Toplantılar", "E-Okul İșlemleri ve diğer", mesleki görevlerine yönelik zaman kullanımı düzeyleri ile "Genel Zaman Kullanım" düzeylerine ait bulgular verilmiştir.

Tablo 3. Mesleki Görevler ve Bu Görevlere İlişkin Faaliyetlere Yönelik Zaman Kullanımı

\begin{tabular}{|c|c|c|}
\hline & $\overline{\mathbf{x}}$ & $\mathbf{S}$ \\
\hline Öğretme ve Öğretime Hazırlık & 3,43 & 0,69 \\
\hline 1.Yıllık ders planlarını hazırlama (BEP dahil) & 3,04 & 0,95 \\
\hline 2.Kılavuz kitabı veya ders planlarını inceleme( BEP dahil) & 3,46 & 0,82 \\
\hline 3.Öğretim programlarını inceleme & 2,83 & 1,02 \\
\hline 4.Farklı kaynaklardan yararlanma & 3,78 & 0,95 \\
\hline 5.Ödevlere yönelik hazırlıklar & 3,61 & 1,10 \\
\hline $\begin{array}{l}\text { 6.Materyal ve etkinlik kağıtlarını hazırlama, çoğaltma vb. hazırlıklar (BEP olan öğrenciler için } \\
\text { yapılan hazırlıklar dahil) }\end{array}$ & 3,97 & 0,85 \\
\hline $\begin{array}{l}\text { 7.Dersle ilgili olarak bireysel ya da grupla öğretimi içeren faaliyetler (ders dışında } \\
\text { öğrencilerin sorularını cevaplama vb. BEP olan öğrenciler dahil) }\end{array}$ & 3,25 & 1,07 \\
\hline $\begin{array}{l}\text { 8.Belirli gün ve haftalara (Milli bayramlar, törenler ve diğer haftalar) yönelik } \\
\text { çalışmalar(hazırlıklar, faaliyetleri yapma, dosyaların tutulması vb.) }\end{array}$ & 3,50 & 0,88 \\
\hline Ölçme ve Değerlendirme & 3,19 & 0,87 \\
\hline 9.Sınavlara ilişkin hazırlıklar (klasik sınavlar, test vb. BEP olan öğrenciler dahil) & 3,24 & 1,12 \\
\hline 10.Sınavları değerlendirme & 3,31 & 1,15 \\
\hline 11.Alternatif değerlendirme formlarını(Akran, öz değerlendirme) puanlama & 2,52 & 1,18 \\
\hline 12.Ödevleri değerlendirme & 3,37 & 1,11 \\
\hline 13.Öğrencilerin ders ve etkinliklerine katılımlarının değerlendirilmesi & 3,51 & 0,91 \\
\hline
\end{tabular}
hazırlanması, notlandırma vb.)

\begin{tabular}{|c|c|c|}
\hline Mesleki Gelişim & 2,90 & 0,84 \\
\hline 14.Alanla ilgili yayınları (kitap, dergi ve makale) ve yenilikleri takip etme & 2,73 & 1,03 \\
\hline $\begin{array}{l}\text { 15.Alanla ilgili bilimsel ve sanatsal faaliyetlere (seminer, konferans, atölye çalışmaları vb. ) } \\
\text { katılma }\end{array}$ & 2,56 & 0,89 \\
\hline 16.Mesleki gelișim amacıyla meslektașlarla işbirliği(görüşme, birlikte çalışma vb.) yapma & 3,36 & 0,95 \\
\hline 17.Bilgi ve iletişim teknolojilerindeki gelişmeleri takip etme & 2,98 & 1,22 \\
\hline Sosyal Etkinlikler ve Rehberlik & 2,57 & 0,80 \\
\hline 18.Öğrenci Kulübü(Sosyal Kulüp) ve Toplum Hizmeti planını hazırlama & 2,66 & 0,81 \\
\hline $\begin{array}{l}\text { 19.Öğrenci Kulübü ve Toplum Hizmetine ilişkin çalışmalar (Hazırlıklar, faaliyetleri yapma } \\
\text { vb.) }\end{array}$ & 2,46 & 0,97 \\
\hline 20.Rehberlik planını hazırlama & 2,49 & 0,93 \\
\hline 21.Rehberlik faaliyetlerine ilişkin çalışmalar (Hazırlıklar, materyallerin çoğaltılması, vb.) & 2,62 & 1,00 \\
\hline Veli İşbirliği & 3,35 & 0,90 \\
\hline 22.Bireysel veli & 3,93 & 0,92 \\
\hline 23.Genel veli toplantıları (hazırlıklar, tutanaklar ve diğer işler dahil) & 3,59 & 0,94 \\
\hline 24.Veli ziyaretleri (hazırlıklar, tutanaklar ve diğer işler dahil) & 2,77 & 1,22 \\
\hline 25.Veli katılımlı faaliyetleri düzenleme ve katılma & 3,12 & 1,06 \\
\hline
\end{tabular}




\begin{tabular}{|c|c|c|}
\hline Kurul, Komisyon ve Toplantılar & 2,74 & 0,83 \\
\hline $\begin{array}{l}\text { 26.0kul zümre öğretmenler kurulu toplantılarına yönelik gerekli hazırlıkları yapma, katılma } \\
\text { ve tutanakları hazırlama }\end{array}$ & 3,13 & 0,88 \\
\hline $\begin{array}{l}\text { 27.Öğretmenler Kurulu toplantılarına yönelik gerekli hazırlıkları yapma, katılma ve } \\
\text { tutanakları hazırlama }\end{array}$ & 3,02 & 0,90 \\
\hline $\begin{array}{l}\text { 28.0kul gelişim yönetim ekibi(OGYE), birim, kurul ve komisyon toplantılarına yönelik gerekli } \\
\text { hazırlıkları yapma ve katılma, }\end{array}$ & 2,52 & 0,98 \\
\hline $\begin{array}{l}\text { 29.0kul gelişim yönetim ekibi(OGYE), birim, kurul ve komisyon görevlerinizi gerçekleştirme } \\
\text { ve raporları hazırlama }\end{array}$ & 2,56 & 0,91 \\
\hline 30.Ekip, Birim, kurul ve komisyonlarla işbirliği yapma & 2,49 & 1,06 \\
\hline $\begin{array}{l}\text { 31.İdarece yapılan diğer toplantılara yönelik gerekli hazırlıkları yapma, katılma ve } \\
\text { tutanakları hazırlama }\end{array}$ & 2,70 & 1,04 \\
\hline E-Okul İşlemleri ve diğer & 3,36 & 0,88 \\
\hline 32. E-okula ders notlarını, davr & 3,61 & 0,98 \\
\hline 33. E-Okul & 3,61 & 0,97 \\
\hline e getirme (süt, yardım & 3,15 & 1,10 \\
\hline 35. Resmi yazlları takip etme ve imzalama & 3,07 & 1,04 \\
\hline Genel Zaman Kullanımı & 3,10 & 0,62 \\
\hline
\end{tabular}

Tablo 3 incelendiğinde; öğretmenlerin "öğretme ve öğretime hazırlık" görevi ortalama puanların yüksek düzeyde $(\bar{x}=3,43, s=0,69)$ olduğu söylenilebilir. Öğretmenlerin bu boyut için en fazla zamanı "Materyal ve etkinlik kağıtlarını hazırlama, çoğaltma vb. hazırlıklarına, (BEP olan öğrenciler için yapılan hazırlıklar dahil)" ( $\overline{\mathrm{x}}=3,97, \mathrm{~s}=0,85)$, en az zaman ise "Öğretim programlarını inceleme" ( $\overline{\mathrm{x}}=2,83, \mathrm{~s}=1,02)$, " faaliyetine ayırdığı görülmektedir.

Öğretmenlerin "Ölçme ve Değerlendirme" görevi ortalama puanlarının "orta" düzeyde $(\bar{x}=3,19$, $s=0,87)$ olduğu söylenilebilir. Öğretmenlerin bu boyut için en fazla zaman ayırdığı faaliyet; "Öğrencilerin ders ve etkinliklere katılımlarının değerlendirilmesi (Ölçeklerin hazırlanması, notlandırma vb.)" ( $\bar{x}=3,51, s=0,91)$ iken öğretmenlerin bu boyut için en az zaman ayırdığı faaliyet ise "Alternatif değerlendirme formlarını (Akran, öz değerlendirme) puanlama" ( $\bar{x}=2,52, s=1,18)$, olduğu görülmektedir.

Öğretmenlerin "Mesleki Gelişim" görevi ortalama puanların "orta" düzeyinde ( $\bar{x}=2,90, s=0,84)$ olduğu söylenilebilir Öğretmenlerin bu boyut için en fazla zaman ayırdığı faaliyet; "Mesleki gelişim amaciyla meslektaşlarla işbirliği (görüşme, birlikte çalışma vb.) yapma" ( $\bar{x}=3,36, s=0,95$ ) iken öğretmenlerin bu boyut için en az zaman ayırdığı faaliyet ise "Alanla ilgili bilimsel ve sanatsal faaliyetlere (seminer, konferans, atölye çalışmaları vb.) katılma" ( $\bar{x}=2,56, s=0,89)$ olduğu görülmektedir.

Öğretmenlerin "Sosyal Etkinlikler ve Rehberlik" görevi ortalama puanlarının "düşük" $(\bar{x}=2,57$, $s=0,80$ ) olduğu söylenilebilir. Öğretmenlerin bu boyut için en fazla zaman ayırdığı faaliyet; Öğrenci Kulübü(Sosyal Kulüp) ve Toplum Hizmeti planını hazırlama" ( $\bar{x}=2,66, s=0,81)$ iken öğretmenlerin bu boyut için en az zaman ayırdığı faaliyet ise "Öğrenci Kulübü ve Toplum Hizmetine ilişkin çalışmalar (Hazırlıklar, faaliyetleri yapma vb.)" ( $\bar{x}=2,46, s=0,97)$ olduğu görülmektedir.

Öğretmenlerin "Veli İșbirliği" görevi ortalama puanlarının "orta" düzeyde $(\bar{x}=3,35, s=0,90)$ olduğu söylenilebilir. Öğretmenlerin bu boyut için en fazla zaman ayırdığı faaliyet; Bireysel veli görüşmeleri (yüz-yüze, telefonla)" ( $\bar{x}=3,93, s=0,92)$ iken öğretmenlerin bu boyut için en az zaman ayırdığı faaliyetin ise "Veli ziyaretleri (hazırlıklar, tutanaklar ve diğer işler dahil)" $(\bar{x}=2,77, s=1,22)$ olduğu görülmektedir.

Öğretmenlerin "Kurul, Komisyon ve Toplantılar" görevi ortalama puanların "orta" düzeyde $(\bar{x}=2,74, s=0,83)$ olduğu söylenilebilir. Öğretmenlerin bu boyut için en fazla zaman ayırdığı faaliyet; "Okul zümre öğretmenler kurulu toplantılarına yönelik gerekli hazırlıkları yapma, katılma ve tutanakları hazırlama $(\overline{\mathrm{x}}=3,13, \mathrm{~s}=0,82)$ iken öğretmenlerin bu boyut için en az zaman ayırdığı faaliyetin ise sırasıyla "Ekip, Birim, kurul ve komisyonlarla işbirliği yapma" ( $\bar{x}=2,49, \mathrm{~s}=1,06)$ olduğu görülmektedir.

Öğretmenlerin "E-Okul İşlemleri ve Diğer" görevi ortalama puanlarının "orta” düzeyde $(\bar{x}=3,36, s=0,88)$ olduğu söylenilebilir. Öğretmenlerin bu boyut için en fazla zaman ayırdığı faaliyet; 
"E-Okula öğrenci bilgilerini girme, güncelleme vb." ( $\bar{x}=3,61, s=0,97)$, iken öğretmenlerin bu boyut için en az zaman ayırdığı faaliyetin ise "Resmi yazıları takip etme ve imzalama" ( $\bar{x}=3,07, s=1,04)$ olduğu görülmektedir.

Öğretmenlerin ders saatleri dışında mesleki görevlerine yönelik "Genel Zaman Kullanımı" düzeyi ortalama puanlarının "orta düzeyde" olduğu söylenebilir. Öğretmenlerin mesleki görevlerine yönelik zaman kullanımı en fazladan en aza doğru sırası ile: "Öğretme ve öğretime hazırlık", "E-Okul işlemleri ve diğer", "veli işbirliği", "ölçme ve değerlendirme”, "mesleki gelişim", "kurul ve komisyon ve toplantılar" ve son olarak "sosyal etkinlikler ve rehberlik" şeklindedir. Öğretmenler mesleki faaliyetler arasında en az zamanı "Öğrenci Kulübü ve Toplum Hizmetine ilişkin çalışmalara (Hazırlıklar, faaliyetleri yapma vb.)" en fazla zamanı ise "Materyal ve etkinlik kağıtlarını hazırlama, çoğaltma vb. hazırlıklar (BEP olan öğrenciler için yapılan hazırlıklar dahil)” için ayırmaktadır.

\section{Araştırmanın İkinci Alt Problemine İliş̧kin Bulgular}

Bu bölümde araștırmanın ikinci alt problemine yönelik olarak, sınıf öğretmenlerinin ders saatleri dışında mesleki görevlerine yönelik zaman kullanımı düzeylerine ilişkin elde edilen nicel veriler cinsiyet, mesleki deneyim, öğrenci sayısı, sınıf düzeyi ve mezun olunan kuruma göre analiz edilmiştir. Sürekli değişken özelliği taşıyan verilerin karşılaştırmalı analizlerinde öncelikle parametrik test varsayımları test edilmiş, bu amaçla dağılımların normal olma durumuna bakılmıştır. Dağılımların normal olduğu tespit edilmiş ve karşılaştırmalar grup sayısına göre; bağımsız örneklemler t testi veya ANOVA ile yapılmıștır.

Tablo 4. Cinsiyet Değişkenine Göre Mesleki Görevlere Yönelik Zaman Kullanımı Düzeyi Puanları ve t Testi Sonuçları

\begin{tabular}{|c|c|c|c|c|c|c|c|c|}
\hline $\begin{array}{l}\text { Zaman } \\
\text { Kullanımı }\end{array}$ & Cinsiyet & $\mathrm{n}$ & $\bar{x}$ & $\mathrm{~S}$ & sd & $\mathrm{t}$ & $\mathrm{p}$ & Anlam \\
\hline \multirow{2}{*}{$\begin{array}{l}\text { Öğretme ve } \\
\text { Öğretime Hazırlık }\end{array}$} & Kadın & 226 & 3,50 &, 72 & \multirow{2}{*}{412} & \multirow{2}{*}{2,35} & \multirow{2}{*}{0,019} & \multirow{2}{*}{$*$} \\
\hline & Erkek & 188 & 3,34 & ,65 & & & & \\
\hline \multirow{2}{*}{$\begin{array}{l}\text { Ölçme ve } \\
\text { Değerlendirme }\end{array}$} & Kadın & 226 & 3,27 & ,88 & \multirow{2}{*}{412} & \multirow{2}{*}{2,07} & \multirow{2}{*}{0,039} & \multirow{2}{*}{$*$} \\
\hline & Erkek & 188 & 3,09 & ,85 & & & & \\
\hline \multirow{2}{*}{ Mesleki Gelişim } & Kadın & 226 & 2,92 & ,84 & \multirow{2}{*}{412} & \multirow{2}{*}{0,39} & \multirow{2}{*}{0,697} & \multirow{2}{*}{-} \\
\hline & Erkek & 188 & 2,89 & ,84 & & & & \\
\hline \multirow{2}{*}{$\begin{array}{l}\text { Sosyal Etkinlikler } \\
\text { ve Rehberlik }\end{array}$} & Kadın & 226 & 2,54 & ,80 & \multirow{2}{*}{412} & \multirow{2}{*}{0,58} & \multirow{2}{*}{0,565} & \multirow{2}{*}{-} \\
\hline & Erkek & 188 & 2,58 & ,81 & & & & \\
\hline \multirow{2}{*}{ Veli İşbirliği } & Kadın & 226 & 3,48 & ,91 & \multirow{2}{*}{412} & \multirow{2}{*}{3,12} & \multirow{2}{*}{0,002} & \multirow{2}{*}{$*$} \\
\hline & Erkek & 188 & 3,20 & ,87 & & & & \\
\hline \multirow{2}{*}{$\begin{array}{l}\text { Kurul, Komisyon } \\
\text { ve Toplantılar }\end{array}$} & Kadın & 226 & 2,78 & ,84 & \multirow{2}{*}{412} & \multirow{2}{*}{1,02} & \multirow{2}{*}{0,306} & \multirow{2}{*}{-} \\
\hline & Erkek & 188 & 2,69 & ,82 & & & & \\
\hline \multirow{2}{*}{$\begin{array}{l}\text { E- Okul İşlemleri } \\
\text { ve diğer }\end{array}$} & Kadın & 226 & 3,43 & ,91 & \multirow{2}{*}{412} & \multirow{2}{*}{1,76} & \multirow{2}{*}{0,080} & \multirow{2}{*}{-} \\
\hline & Erkek & 188 & 3,28 & ,82 & & & & \\
\hline \multirow{2}{*}{$\begin{array}{l}\text { Genel Zaman } \\
\text { Kullanımı }\end{array}$} & Kadın & 226 & 3,16 & ,63 & & 2.03 & & $*$ \\
\hline & Erkek & 188 & 3,03 & ,61 & 412 & 2,03 & 0,044 & T \\
\hline
\end{tabular}

* $\mathrm{P}<.05$ anlaml

Tablo 4 incelendiğinde öğretmenlerin cinsiyete göre "Öğretme ve Öğretime Hazırlık $[\mathrm{t}(412)=2,35, \mathrm{p}<, 05]$. ., "Ölçme ve Değerlendirme $[\mathrm{t}(412)=2,07, \mathrm{p}<, 05]$ ”, "Veli İşbirliği $[\mathrm{t}(412)=3,12$, $\mathrm{p}<, 05]$ " ve "Genel Zaman Kullanımı [t(412) $=2,03, \mathrm{p}<, 05]$ " puanları arasında anlamlı farklılık görülmekte iken "Mesleki Gelişim [t(412) =0,39, p>,05]", "Sosyal Etkinlikler ve Rehberlik [t(412) $=0,58, \mathrm{p}>, 05]$ ]", "Kurul, Komisyon ve Toplantılar [t(412) =1,02, p>,05]" ve "E- Okul İșlemleri ve Diğer [t(412)=1,76, p>,05]" alt boyutlarında ise anlamlı bir farklılık görülmemiștir.

"Öğretme ve Öğretime Hazırlık" boyutunda kadın öğretmenlerin zaman kullanımı puanları $\left(x^{-}=3,50 \quad s=, 72\right)$ erkek öğretmenlerin puanlarına $\left(\bar{x}^{-}=3,34 \quad s=, 65\right)$ göre daha yüksek "Ölçme ve Değerlendirme" boyutunda kadın öğretmenlerin zaman kullanımı puanları $(x=3,27 s=, 88)$, erkek öğretmenlerin puanlarına $(\bar{x}=3,09 s=, 85)$ göre daha yüksek; "Veli İşbirliği" boyutunda da kadın öğretmenlerin zaman kullanımı puanları $(\bar{x}=3,48 s=, 91)$, erkek öğretmenlerin puanlarına $(\bar{x}=3,20$ 
s=,87) göre daha yüksektir. Başka bir deyişle kadın öğretmenler "Öğretme ve Öğretime Hazırlık", "Ölçme ve Değerlendirme", ve "Veli İşbirliği" görevlerine erkek öğretmenlerden daha fazla zaman ayırmaktadır. Benzer șekilde "Genel Zaman Kullanımı"nda kadın öğretmenlerin zaman kullanımı puanlarının $\left(\mathrm{x}^{-}=3,16 \mathrm{~s}=, 63\right)$, erkek öğretmenlerin puanlarına $\left(\mathrm{x}^{-}=3,03 \mathrm{~s}=, 61\right)$ göre daha yüksek olduğu görülmektedir.

Tablo 5. Mesleki Deneyim Değişkenine Göre Mesleki Görevlere Yönelik Zaman Kullanımı Düzeyi Puanları ve Varyans Analizi Sonuçları

\begin{tabular}{|c|c|c|c|c|c|c|c|}
\hline Zaman Kullanımı & Mesleki Deneyim & $\mathrm{n}$ & $\bar{x}$ & $\mathrm{~s}$ & $\mathrm{~F}$ & $\mathrm{p}$ & Fark-Grup \\
\hline \multirow{5}{*}{$\begin{array}{l}\text { Öğretme ve } \\
\text { Öğretime } \\
\text { Hazırlık }\end{array}$} & 1. 1-5 yll & 36 & 3,95 & ,52 & \multirow{5}{*}{7,855} & \multirow{5}{*}{, $000^{*}$} & \multirow{5}{*}{$\begin{array}{r}1-2,1-3 \\
1-4,1-5\end{array}$} \\
\hline & 2. $6-10 \mathrm{yll}$ & 69 & 3,18 & ,84 & & & \\
\hline & 3. $11-15$ yll & 76 & 3,38 & 71 & & & \\
\hline & 4. $16-20$ yll & 85 & 3,44 & ,66 & & & \\
\hline & 5. 21 yll ve üstü & 148 & 3,44 & ,60 & & & \\
\hline \multirow{5}{*}{$\begin{array}{l}\text { Ölçme ve } \\
\text { Değerlendirme }\end{array}$} & 1. 1-5 yll & 36 & 3,08 & ,97 & \multirow{5}{*}{1,963} & \multirow{5}{*}{,099 } & \multirow{5}{*}{-} \\
\hline & 2. 6-10 yll & 69 & 3,19 & 1,04 & & & \\
\hline & 3. $11-15$ yll & 76 & 2,99 & ,83 & & & \\
\hline & 4. $16-20 \mathrm{yll}$ & 85 & 3,18 & ,85 & & & \\
\hline & 5. 21 yll ve üstü & 148 & 3,32 &, 77 & & & \\
\hline \multirow{5}{*}{ Mesleki Gelişim } & 1. 1-5 yll & 36 & 3,83 & 71 & \multirow{5}{*}{20,308} & \multirow{5}{*}{, $000 *$} & \multirow{5}{*}{$\begin{array}{c}1-2,1-3,1-4 \\
1-5,2-3,3-5 \\
4-5\end{array}$} \\
\hline & 2. 6-10 yll & 69 & 2,90 & ,83 & & & \\
\hline & 3. $11-15$ yll & 76 & 2,51 & ,78 & & & \\
\hline & 4. $16-20 \mathrm{yll}$ & 85 & 2,70 & ,83 & & & \\
\hline & 5. 21 yll ve üstü & 148 & 3,00 &, 70 & & & \\
\hline \multirow{5}{*}{$\begin{array}{l}\text { Sosyal } \\
\text { Etkinlikler ve } \\
\text { Rehberlik }\end{array}$} & 1. 1-5 yll & 36 & 2,87 & ,86 & \multirow{5}{*}{5,008} & \multirow{5}{*}{, $001^{*}$} & \multirow{5}{*}{$\begin{array}{c}1-2,1-3,1-4, \\
5-2,5-3\end{array}$} \\
\hline & 2. 6-10 yl & 69 & 2,36 & ,81 & & & \\
\hline & 3. $11-15 \mathrm{yll}$ & 76 & 2,34 & 80 & & & \\
\hline & 4. $16-20$ yll & 85 & 2,54 & ,81 & & & \\
\hline & 5. 21 yll ve üstü & 148 & 2,70 & ,74 & & & \\
\hline \multirow{5}{*}{ Veli İşbirliği } & 1. 1-5 yll & 36 & 3,47 & 1,16 & \multirow{5}{*}{1,290} & \multirow{5}{*}{ 273 } & \multirow{5}{*}{-} \\
\hline & 2. 6-10 yll & 69 & 3,26 & ,96 & & & \\
\hline & 3. $11-15 \mathrm{yll}$ & 76 & 3,20 & ,94 & & & \\
\hline & 4. $16-20$ yıl & 85 & 3,34 & ,92 & & & \\
\hline & 5. 21 yll ve üstü & 148 & 3,45 &, 76 & & & \\
\hline \multirow{5}{*}{$\begin{array}{l}\text { Kurul, } \\
\text { Komisyon ve } \\
\text { Toplantılar }\end{array}$} & 1. $1-5 \mathrm{yll}$ & 36 & 2,78 & 87 & \multirow{5}{*}{2,583} & \multirow{5}{*}{, $037^{*}$} & \multirow{5}{*}{$5-2,5-3$} \\
\hline & 2. 6-10 yll & 69 & 2,63 & ,86 & & & \\
\hline & 3. $11-15$ yll & 76 & 2,55 & ,79 & & & \\
\hline & 4. $16-20$ yll & 85 & 2,72 & 91 & & & \\
\hline & 5. 21 yll ve üstü & 148 & 2,89 &, 76 & & & \\
\hline \multirow{5}{*}{$\begin{array}{l}\text { E- Okul } \\
\text { İşlemleri ve } \\
\text { diğger }\end{array}$} & 1. 1-5 yıl & 36 & 3,54 & ,80 & & & \\
\hline & 2. $6-10 \mathrm{yll}$ & 69 & 3,28 & ,90 & & & \\
\hline & 3. $11-15$ yll & 76 & 3,16 & ,86 & 1,820 & 124 & - \\
\hline & 4. $16-20 \mathrm{yll}$ & 85 & 3,41 & ,94 & & & \\
\hline & 5. 21 yll ve üstü & 148 & 3,42 & ,84 & & & \\
\hline & 1. 1-5 yil & 36 & 3,39 & ,46 & & & \\
\hline Genel 7 & 2. 6-10 yll & 69 & 2,99 & ,76 & & & \\
\hline $\begin{array}{l}\text { Kullanımı } \\
\text { Kell }\end{array}$ & 3. $11-15$ yll & 76 & 2,91 & 60 & 5,218 &, $00^{*}$ & $1-4,3-5$ \\
\hline & 4. $16-20$ yl & 85 & 3,08 & ,63 & & & \\
\hline & 5. 21 yll ve üstü & 148 & 3,19 & ,55 & & & \\
\hline
\end{tabular}


Tablo 5 incelendiğinde öğretmenlerin mesleki deneyime göre mesleki görevlerine yönelik zaman kullanımı ölçeğinden almış oldukları puan ortalamaları arasındaki farkın anlamlılığını test etmek için yapılan varyans analizi sonucunda "Öğretme ve Öğretime Hazırlık $(F=7,855, p<0.05)$ " ,"Mesleki Gelişim ( $\mathrm{F}=20,308, \mathrm{p}<0.05)$ ", "Sosyal Etkinlikler ve Rehberlik ( $\mathrm{F}=5,008, \mathrm{p}<0.05)$ ), "Kurul, Komisyon ve Toplantılar ( $\mathrm{F}=2,583, \mathrm{P}<0.05)$ " alt boyutları ile "Genel Zaman Kullanımı $(\mathrm{F}=5,218$, $\mathrm{p}<0.05)$ " puanları arasında anlamlı bir farklılık olduğu, "Ölçme ve Değerlendirme $(\mathrm{F}=1,963, \mathrm{p}>0.05)$ ", "Veli İşbirliği $(F=1,290, p>0.05)$ " ve "E- Okul İşlemleri ve diğer $(F=5,218, \quad p>0.05)$ " görevleri arasında anlamlı bir farklılık olmadığı görülmüştür.

Öğretmenlerin "Öğretme ve Öğretime Hazırlık" alt boyutu puanları ortalamaları arasındaki farklılığın hangi gruplardan kaynaklandığını tespit etmek için yapılan Dunnet C testi sonucuna göre, mesleki deneyimi 1-5 yıl arasında olan öğretmenlerin "Öğretme ve Öğretime Hazırlık" puanlarının $(\bar{x}=3,95 \mathrm{~s}=, 52), 6-10$ yll $(\bar{x}=3,18 \mathrm{~s}=, 84), 11-15$ yll $(\bar{x}=3,38 \mathrm{~s}=, 71), 16-20$ yll $(\bar{x}=3,44 \mathrm{~s}=, 66)$ ve 21 yll ve üstü $(\bar{x}=3,44 \mathrm{~s}=, 60)$ mesleki deneyime sahip öğretmenlerden daha yüksek olduğu görülmüştür.

Öğretmenlerin "Mesleki Gelişim" alt boyutu puanları ortalamaları arasındaki farklılığın hangi gruplardan kaynaklandığını tespit etmek için yapılan Dunnet $C$ testi sonucuna göre, mesleki deneyimi 1-5 yıl arasında olan öğretmenlerin "Mesleki Gelişim" puanlarının $(\bar{x}=3,83 \mathrm{~s}=, 71)$ mesleki deneyimi 6-10 yll ( $\bar{x}=2,90 \mathrm{~s}=, 83), 11-15$ yll $(\bar{x}=2,51 \mathrm{~s}=, 78) 16-20$ yll $(\bar{x}=2,70 \mathrm{~s}=, 83)$ ve 21 yll ve üstü $(\bar{x}=3,00 \mathrm{~s}=, 70)$ olan öğretmenlerin puanlarından daha fazla olduğu görülmüştür.

Öğretmenlerin "Sosyal Etkinlikler ve Rehberlik" alt boyutu puanları ortalamaları arasındaki farklılı̆̆ın hangi gruplardan kaynaklandığını tespit etmek için yapılan LSD testi, sonucuna göre, mesleki deneyimi 1-5 yll $(\bar{x}=2,87 \mathrm{~s}=, 86)$ arasında olan öğretmenlerin "Sosyal Etkinlikler ve Rehberlik" puanlarının, mesleki deneyimi 6-10 yll ( $\bar{x}=2,36 \mathrm{~s}=, 81), 11-15$ yll $(\bar{x}=2,34 \mathrm{~s}=, 80)$ ve $16-20$ yll $(\bar{x}=2,54 \mathrm{~s}=, 81)$ olan öğretmenlerin puanlarından daha yüksek olduğu görülmüştür. Mesleki deneyimi 21 yll ve üstü $(\bar{x}=2,70 s=, 74)$ olan öğretmenlerin "Sosyal Etkinlikler ve Rehberlik" puanlarının da mesleki deneyimi 6-10 yll $(\bar{x}=2,36 \mathrm{~s}=, 81)$ ve $11-15$ yll $(\bar{x}=2,34 \mathrm{~s}=, 80)$ olan öğretmenlerin puanlarından daha yüksek olduğu görülmüștür..

Öğretmenlerin "Kurul, Komisyon ve Toplantılar" alt boyutu puanları ortalamaları arasındaki farklılığın hangi gruplardan kaynaklandığını tespit etmek için yapılan LSD testi, sonucuna göre, mesleki deneyimi 21 yıl ve üstü olan öğretmenlerin puanlarının $(\bar{x}=2,89 \mathrm{~s}=, 76) 6-10$ yll $\quad(\bar{x}=2,63$ $s=, 86)$ ve 11-15yll $(\bar{x}=2,55 s=, 79)$ mesleki deneyime sahip öğretmenlerden daha yüksek olduğu görülmüştür.

Öğretmenlerin "Genel zaman kullanımı” puanları ortalamaları arasındaki farklılığın hangi gruplardan kaynaklandığını tespit etmek için yapılan Dunnet $\mathrm{C}$ testi sonucuna göre, mesleki deneyimi 1-5 yıl $(\bar{x}=3,39 \mathrm{~s}=, 46)$ arasında olan öğretmenlerin "Genel Zaman Kullanımı" puanlarının, mesleki deneyimi 6-10 yll ( $\bar{x}=2,99 \mathrm{~s}=, 76), 11-15$ yll $(\bar{x}=2,91 \mathrm{~s}=, 60)$ ve $16-20$ yll $(\bar{x}=3,08 \mathrm{~s}=, 63)$ olan öğretmenlerin puanlarından daha yüksek olduğu görülmüştür. Mesleki deneyimi 21 yll ve üstü $(\bar{x}=3,08 \mathrm{~s}=, 63)$ olan ögretmenlerin "Genel Zaman Kullanımı" puanlarının da mesleki deneyimi 11-15 yll $(\bar{x}=2,91 \mathrm{~s}=, 60)$ olan öğretmenlerin puanlarından daha yüksektir. 
Tablo 6. Öğrenci Sayısı Değişkenine Göre Mesleki Görevlere Yönelik Zaman Kullanımı Düzeyi Puanları ve Varyans Analizi Sonuçları

\begin{tabular}{|c|c|c|c|c|c|c|c|}
\hline Zaman Kullanımı & $\begin{array}{c}\text { Öğrenci } \\
\text { Sayısı }\end{array}$ & $\mathrm{n}$ & $\bar{x}$ & $\mathrm{~S}$ & $\mathrm{~F}$ & $\mathrm{p}$ & Fark-Grup \\
\hline \multirow{4}{*}{$\begin{array}{l}\text { Öğretme ve } \\
\text { Öğretime Hazırlık }\end{array}$} & 1. $1-10$ & 28 & 2,83 & ,86 & \multirow{4}{*}{8,043} & \multirow{4}{*}{, $000 *$} & \multirow{4}{*}{$1-2,1-3,1-4$} \\
\hline & 2. $11-20$ & 188 & 3,47 & 67 & & & \\
\hline & 3. $21-30$ & 138 & 3,50 & 63 & & & \\
\hline & $\begin{array}{l}\text { 4. } 31 \text { ve } \\
\text { üstü }\end{array}$ & 60 & 3,43 & ,70 & & & \\
\hline \multirow{4}{*}{$\begin{array}{l}\text { Ölçme ve } \\
\text { Değerlendirme }\end{array}$} & 1. $1-10$ & 28 & 2,26 & 80 & \multirow{4}{*}{12,580} & \multirow{4}{*}{, $000 *$} & \multirow{4}{*}{$1-2,1-3,1-4$} \\
\hline & 2. $11-20$ & 188 & 3,27 & 81 & & & \\
\hline & 3. $21-30$ & 138 & 3,23 & ,86 & & & \\
\hline & $\begin{array}{l}\text { 4. } 31 \text { ve } \\
\text { üstü } \\
\end{array}$ & 60 & 3,27 & ,87 & & & \\
\hline \multirow{4}{*}{ Mesleki Gelişim } & 1. $1-10$ & 28 & 2,29 & ,96 & \multirow{4}{*}{8,763} & \multirow{4}{*}{, $000 *$} & \multirow{4}{*}{$1-2,1-3$} \\
\hline & 2. $11-20$ & 188 & 2,98 & ,74 & & & \\
\hline & 3. $21-30$ & 138 & 3,03 & ,82 & & & \\
\hline & $\begin{array}{l}\text { 4. } 31 \text { ve } \\
\text { üstü }\end{array}$ & 60 & 2,67 & ,94 & & & \\
\hline \multirow{4}{*}{$\begin{array}{l}\text { Sosyal Etkinlikler ve } \\
\text { Rehberlik }\end{array}$} & 1. $1-10$ & 28 & 2,00 & ,72 & \multirow{4}{*}{7,364} & \multirow{4}{*}{, $000 *$} & \multirow{4}{*}{$\begin{array}{l}1-2,1-3 \\
4-2,4-3\end{array}$} \\
\hline & 2. $11-20$ & 188 & 2,63 & ,80 & & & \\
\hline & 3. $21-30$ & 138 & 2,66 & ,79 & & & \\
\hline & $\begin{array}{l}\text { 4. } 31 \text { ve } \\
\text { üstü }\end{array}$ & 60 & 2,35 & ,75 & & & \\
\hline \multirow{4}{*}{ Veli İşbirliği } & 1. $1-10$ & 28 & 2,79 & 1,01 & \multirow{4}{*}{4,537} & \multirow{4}{*}{, $004^{*}$} & \multirow{4}{*}{$1-2,1-3,1-4$} \\
\hline & 2. $11-20$ & 188 & 3,44 & ,83 & & & \\
\hline & 3. $21-30$ & 138 & 3,38 & ,89 & & & \\
\hline & $\begin{array}{l}\text { 4. } 31 \text { ve } \\
\text { üstü }\end{array}$ & 60 & 3,27 & ,99 & & & \\
\hline \multirow{4}{*}{$\begin{array}{l}\text { Kurul, Komisyon ve } \\
\text { Toplantılar }\end{array}$} & 1. $1-10$ & 28 & 2,14 & ,85 & \multirow{4}{*}{9,362} & \multirow{4}{*}{,000* } & \multirow{4}{*}{$\begin{array}{l}1-2,1-3 \\
1-4,2-4\end{array}$} \\
\hline & 2. $11-20$ & 188 & 2,90 & ,80 & & & \\
\hline & 3. $21-30$ & 138 & 2,73 & ,80 & & & \\
\hline & $\begin{array}{l}\text { 4. } 31 \text { ve } \\
\text { üstü }\end{array}$ & 60 & 2,51 & ,84 & & & \\
\hline \multirow{4}{*}{$\begin{array}{l}\text { E- Okul İşlemleri ve } \\
\text { diğer }\end{array}$} & 1. $1-10$ & 28 & 2,70 & ,93 & \multirow{4}{*}{7,797} & \multirow{4}{*}{, $000^{*}$} & \multirow{4}{*}{$\begin{array}{l}1-2,1-3 \\
1-4,2-4\end{array}$} \\
\hline & 2. $11-20$ & 188 & 3,47 & 90 & & & \\
\hline & 3. $21-30$ & 138 & 3,43 & ,81 & & & \\
\hline & $\begin{array}{l}\text { 4. } 31 \text { ve } \\
\text { üstü }\end{array}$ & 60 & 3,18 & ,78 & & & \\
\hline \multirow{4}{*}{$\begin{array}{l}\text { Genel Zaman } \\
\text { Kullanımı }\end{array}$} & 1. $1-10$ & 28 & 2,45 & ,76 & & & \\
\hline & 2. $11-20$ & 188 & 3,19 & 60 & & $000 *$ & $1-2,1-3$ \\
\hline & 3. $21-30$ & 138 & 3,16 &, 56 & 13,575 & , & $1-4,2-4$ \\
\hline & $\begin{array}{l}\text { 4. } 31 \text { ve } \\
\text { üstü }\end{array}$ & 60 & 2,99 & ,59 & & & \\
\hline
\end{tabular}

Tablo 6 incelendiğinde öğretmenlerin sınıflarındaki öğrenci sayısına göre mesleki görevlerine yönelik zaman kullanımı ölçeğinden almış oldukları puan ortalamaları arasındaki farkın anlamlılığını test etmek için yapılan varyans analizi sonucunda, alt boyutların tamamında ve "Genel Zaman Kullanımı” puanları arasında anlamlı farklılık olduğu görülmüştür. Aşağıda öğretmenlerin öğrenci sayısına göre göre puan dağılımları ve anova sonuçları sırasıyla verilmektedir. 
Öğretmenlerin öğrenci sayısına göre "Öğretme ve Öğretime Hazırlık" (F=8,043, p<0.05) puan ortalamaları arasında anlamlı bir farklılık bulunmuştur. "Öğretme ve Öğretime Hazırlık" alt boyutu puan ortalamaları arasındaki farklılığın hangi gruplardan kaynaklandığını tespit etmek için yapılan Dunnet $C$ testi sonucuna göre, öğrenci sayısı 1-10 arasında olan öğretmenlerin "öğretme ve öğretime hazırlık" puanlarının ( $\bar{x}=2,83 \mathrm{~s}=, 86)$, öğrenci sayısı 11-20 ( $\bar{x}=3,47 \mathrm{~s}=, 67), 21-30 \quad(\bar{x}=3,50 \mathrm{~s}=, 63)$ ve 31 ve üstü $(\bar{x}=3,43 \mathrm{~s}=, 70)$ olan öğretmenlerin puanlarından daha düşük olduğu görülmüştür.

Öğretmenlerin öğrenci sayısına göre "Ölçme ve Değerlendirme" ( $F=12,580, p<0.05)$ puan ortalamaları arasında anlamlı bir farklılık bulunmuştur. "Ölçme ve Değerlendirme" alt boyutu puan ortalamaları arasındaki farklılığın hangi gruplardan kaynaklandığını tespit etmek için yapılan LSD testi sonucuna göre, öğrenci sayısı 1-10 arasında olan öğretmenlerin "ölçme ve değerlendirme" puanlarının $(\bar{x}=2,26 \mathrm{~s}=, 80)$ öğrenci sayısı 11-20 ( $\bar{x}=3,27 \mathrm{~s}=, 81), 21-30(\bar{x}=3,23 \mathrm{~s}=, 86)$ ve 31 ve üstü $(\bar{x}=3,27 \mathrm{~s}=, 87)$ olan öğretmenlerin puanlarından daha düşük olduğu görülmüştür.

Öğretmenlerin öğrenci sayısına göre "Mesleki Gelişim" (F=8,763, $p<0.05)$ puan ortalamaları arasında anlamlı bir farklılık bulunmuştur. "Mesleki Gelişim" alt boyutu puan ortalamaları arasındaki farkın hangi gruplardan kaynaklandığını tespit etmek için yapılan Dunnet C testi sonucuna göre, öğrenci sayısı 1-10 arasında olan öğretmenlerin "Mesleki Gelişim" puanlarının $(\bar{x}=2,29 \mathrm{~s}=, 96)$, öğrenci sayısı 11-20 ( $\bar{x}=2,98 \mathrm{~s}=, 74)$ ve 21-30 $(\bar{x}=3,03 \mathrm{~s}=, 82)$ olan öğretmenlerin puanlarından daha düşük olduğu görülmüştür.

Öğretmenlerin öğrenci sayısına göre "Sosyal Etkinlikler ve Rehberlik" $(F=7,364, p<0.05)$ puan ortalamaları arasında anlamlı bir farklılık bulunmuştur. "Sosyal Etkinlikler ve Rehberlik" alt boyutu puanları ortalamaları arasındaki farklılığın hangi gruplardan kaynaklandığını tespit etmek için yapılan LSD testi, sonucuna göre, öğrenci sayısı 1-10 arasında olan öğretmenlerin "Sosyal Etkinlikler ve Rehberlik" puanlarının ( $\bar{x}=2,00 s=, 72)$, öğrenci sayısı $11-20(\bar{x}=2,63 \mathrm{~s}=, 80)$ ve $21-30(\bar{x}=2,66$ $s=, 79)$ olan öğretmenlerden; öğrenci sayısı 31 ve üstü $(\bar{x}=2,35 s=, 52)$ olan öğretmenlerin puanlarının da öğrenci sayısı 11-20 ( $\bar{x}=2,63 \mathrm{~s}=, 80)$ ve 21-30 $(\bar{x}=2,66 \mathrm{~s}=, 79)$ olan öğretmenlerin puanlarından daha düşük olduğu görülmüștür.

Öğretmenlerin öğrenci sayısına göre "Veli İşbirliği" $(F=4,537, p<0.05)$ puan ortalamaları arasında anlamlı bir farklılık bulunmuştur. "Veli İşbirliği" alt boyutu puan ortalamaları arasındaki farklılığın hangi gruplardan kaynaklandığını tespit etmek için yapılan LSD testi sonucuna göre, öğrenci sayısı 1-10 arasında olan öğretmenlerin Veli İşbirliği puanlarının $(\bar{x}=2,79 \mathrm{~s}=1,01)$, öğrenci sayısı 11-20 ( $\bar{x}=3,44 \mathrm{~s}=, 83), 21-30(\bar{x}=3,38 \mathrm{~s}=, 89)$ ve 31 ve üstü $(\bar{x}=3,27 \mathrm{~s}=, 99)$ olan öğretmenlerin puanlarından daha az olduğu görülmüştür.

Öğretmenlerin öğrenci sayısına göre "Kurul, Komisyon ve Toplantılar" ( $F=9,362, p<0.05)$ puan ortalamaları arasında anlamlı bir farklılık bulunmuştur. "Kurul, Komisyon ve Toplantılar" alt boyutu puan ortalamaları arasındaki farklılığın hangi gruplardan kaynaklandığını tespit etmek için yapılan LSD testi, sonucuna göre, öğrenci sayısı 1-10 arasında olan öğretmenlerin "Kurul, Komisyon ve Toplantılar" puanlarının ( $\bar{x}=2,14 \mathrm{~s}=, 85)$, öğrenci sayısı 11-20 ( $\bar{x}=2,90 \mathrm{~s}=, 80) 21-30(\bar{x}=2,73 \mathrm{~s}=, 80)$ ve 31 ve üstü $(\bar{x}=2,51 \mathrm{~s}=, 84)$ olan öğretmenlerden; öğrenci sayısı 31 ve üstü $(\bar{x}=2,51 \mathrm{~s}=, 84)$ olan öğretmenlerin puanlarının da öğrenci sayısı 11-20 ( $\bar{x}=2,90 s=, 80)$ olan öğretmenlerin puanlarından daha düşük olduğu görülmüştür.

Öğretmenlerin öğrenci sayısına göre "E- Okul İşlemleri ve diğer" (F=7,797, $p<0.05)$ puan ortalamaları arasında anlamlı bir farklılık bulunmuştur. "E- Okul İşlemleri ve diğer" alt boyutu puan ortalamaları arasındaki farklılığın hangi gruplardan kaynaklandığını tespit etmek için yaplan LSD testi sonucuna göre, öğrenci sayısı 1-10 arasında olan öğretmenlerin "E- Okul İşlemleri ve diğer" puanlarının $(\bar{x}=2,70 \mathrm{~s}=, 93)$ öğrenci sayısı 11-20 ( $\bar{x}=3,47 \mathrm{~s}=, 90), 21-30(\bar{x}=3,43 \mathrm{~s}=, 81)$ ve 31 ve üstü $(\bar{x}=3,18 \mathrm{~s}=, 78)$ olan öğretmenlerin puanlarından daha düşük olduğu, 31 ve üstü $(\bar{x}=3,18 \mathrm{~s}=, 78)$ olan öğretmenlerin de öğrenci sayısı 11-20 ( $\bar{x}=3,47 s=, 90)$ olan öğretmenlerin puanlarından daha düşük olduğu görülmüștür..

Öğretmenlerin öğrenci sayısına göre "Genel Zaman Kullanımı" $(F=13,575, p<0.05)$ puan ortalamaları arasında anlamlı bir farklılık bulunmuştur. "Genel Zaman Kullanımı" puan ortalamaları arasındaki farklılığın hangi gruplardan kaynaklandığını tespit etmek için yapılan LSD testi sonucuna göre, öğrenci sayısı 1-10 arasında olan öğretmenlerin "Genel Zaman Kullanımı" puanlarının $(\bar{x}=2,45$ $s=, 76)$, öğrenci sayısı 11-20 ( $\bar{x}=3,19 \mathrm{~s}=, 60) 21-30(\bar{x}=3,16 \mathrm{~s}=, 56)$ ve 31 ve üstü $(\bar{x}=2,99 \mathrm{~s}=, 56)$ olan öğretmenlerin puanlarından daha düşük olduğu görülmüștür. 31 ve üstü $(\bar{x}=2,99 s=, 56)$ olan 
öğretmenlerin de öğrenci sayısı 11-20 ( $\bar{x}=3,19 \mathrm{~s}=, 60)$ olan öğretmenlerin puanlarından daha az olduğu görülmüştür.

Tablo 7. Sınıf Düzeyi Değişkenine Göre Mesleki Görevlere Yönelik Zaman Kullanımı Düzeyi Puanları ve Varyans Analizi Sonuçları

\begin{tabular}{|c|c|c|c|c|c|c|c|}
\hline Zaman Kullanımı & $\begin{array}{c}\text { Sinif } \\
\text { Kademesi }\end{array}$ & $\mathrm{n}$ & $\bar{x}$ & $\mathrm{~s}$ & $\mathrm{~F}$ & $\mathrm{p}$ & Fark-Grup \\
\hline \multirow{4}{*}{$\begin{array}{l}\text { Öğretme ve Öğretime } \\
\text { Hazırllk }\end{array}$} & 1. 1.sinıf & 99 & 3,67 & 57 & \multirow{4}{*}{11,170} & \multirow{4}{*}{, $000^{*}$} & \multirow{4}{*}{$\begin{array}{l}1-2,1-3 \\
4-2,4-3\end{array}$} \\
\hline & 2. 2.sinif & 98 & 3,20 & ,73 & & & \\
\hline & 3. 3.sinıf & 124 & 3,30 & ,75 & & & \\
\hline & 4. 4.sinıf & 93 & 3,60 & ,59 & & & \\
\hline \multirow{4}{*}{$\begin{array}{l}\text { Ölçme ve } \\
\text { Değerlendirme }\end{array}$} & 1. 1.sinif & 99 & 2,76 & 88 & \multirow{4}{*}{27,118} & \multirow{4}{*}{, $000^{*}$} & \multirow{4}{*}{$\begin{array}{c}3-1,3-2 \\
4-1,4-2,4-3\end{array}$} \\
\hline & 2. 2.sinif & 98 & 2,98 & ,93 & & & \\
\hline & 3. 3.sinıf & 124 & 3,30 & ,79 & & & \\
\hline & 4. 4.sinıf & 93 & 3,73 &, 51 & & & \\
\hline \multirow{4}{*}{ Mesleki Gelişim } & 1. $1 . \operatorname{sinif}$ & 99 & 2,94 & 88 & \multirow{4}{*}{ 190 } & \multirow{4}{*}{903} & \multirow{4}{*}{ - } \\
\hline & 2. 2.sinıf & 98 & 2,87 & ,83 & & & \\
\hline & 3. 3.sinif & 124 & 2,88 & ,78 & & & \\
\hline & 4. $4 . \sin 1 f$ & 93 & 2,93 & 87 & & & \\
\hline \multirow{4}{*}{$\begin{array}{l}\text { Sosyal Etkinlikler ve } \\
\text { Rehberlik }\end{array}$} & 1. $1 . \sin ı f$ & 99 & 2,44 & ,78 & \multirow{4}{*}{4,349} & \multirow{4}{*}{, $005^{*}$} & \multirow{4}{*}{$4-1,4-2,4-3$} \\
\hline & 2. $2 . \sin 1 f$ & 98 & 2,46 & 86 & & & \\
\hline & 3. 3.sinif & 124 & 2,53 & ,79 & & & \\
\hline & 4. 4.sinif & 93 & 2,80 &, 73 & & & \\
\hline \multirow{4}{*}{ Veli İşbirliği } & 1. 1.sinif & 99 & 3,98 & 83 & \multirow{4}{*}{26,229} & \multirow{4}{*}{, $000^{*}$} & \multirow{4}{*}{$1-2,1-3,1-4$} \\
\hline & 2. $2 . \sin ı f$ & 98 & 3,19 & ,87 & & & \\
\hline & 3. 3.sinif & 124 & 3,20 & ,72 & & & \\
\hline & 4. 4.sinıf & 93 & 3,04 & ,91 & & & \\
\hline \multirow{4}{*}{$\begin{array}{l}\text { Kurul, Komisyon ve } \\
\text { Toplantılar }\end{array}$} & 1. $1 . \sin ı f$ & 99 & 2,65 & 80 & \multirow{4}{*}{,624 } & \multirow{4}{*}{, $600^{*}$} & \multirow{4}{*}{-} \\
\hline & 2. $2 . \operatorname{sinif}$ & 98 & 2,73 & 84 & & & \\
\hline & 3. 3.sinif & 124 & 2,80 & 84 & & & \\
\hline & 4. 4.sinif & 93 & 2,77 &, 84 & & & \\
\hline \multirow{4}{*}{$\begin{array}{l}\text { E- Okul İşlemleri ve } \\
\text { diğer }\end{array}$} & 1. $1 . \sin ı f$ & 99 & 3,28 & 80 & \multirow{4}{*}{2,211} & \multirow{4}{*}{,086* } & \multirow{4}{*}{ - } \\
\hline & 2. $2 . \sin 1 f$ & 98 & 3,31 & ,93 & & & \\
\hline & 3. 3.sinif & 124 & 3,30 & ,93 & & & \\
\hline & 4. 4.sinif & 93 & 3,56 & ,79 & & & \\
\hline \multirow{4}{*}{$\begin{array}{l}\text { Genel Zaman } \\
\text { Kullanımı }\end{array}$} & 1. 1.sinıf & 99 & 3,13 & ,51 & & & \\
\hline & 2. $2 . \sin I f$ & 98 & 2,98 & ,71 & 3.100 & $027^{*}$ & $2-4$ \\
\hline & 3. 3.sinıf & 124 & 3,07 & ,67 & 3,100 &, $027^{*}$ & $Z-4$ \\
\hline & 4. 4.sinif & 93 & 3,24 &, 53 & & & \\
\hline
\end{tabular}

$\mathrm{p}<0.05$ anlaml

Tablo 7 incelendiğinde öğretmenlerin sınıf düzeyine göre mesleki görevlerine yönelik zaman kullanımı ölçeğinden almış oldukları puan ortalamaları arasındaki farkın manidarlığını test etmek için yapılan varyans analizi sonucunda "Öğretme ve Öğretime Hazırlık $(F=11,70, p<0.05)$ ", "Ölçme ve Değerlendirme $(F=27,18, p<0.05)$ ", "Sosyal Etkinlikler ve Rehberlik" $(F=4,349, p<0.05)$ ", "Veli İşbirliği $(\mathrm{F}=26,229, \mathrm{p}<0.05)$ " alt boyutları ile "Genel Zaman Kullanımı $(\mathrm{F}=3,100, \mathrm{p}<0.05)$ " puanları 
arasında anlamlı bir farklılık olduğu, ,"Mesleki Gelişim (F=0,190, p>.05)”, "Kurul, Komisyon ve Toplantılar $(\mathrm{F}=0,624, \mathrm{p}>0.05)$ " ve "E- Okul İşlemleri ve diğer $(\mathrm{F}=0,624, \mathrm{p}>0.05)$ " görevleri arasında anlamlı bir farklılık olmadığı görülmüştür.

"Öğretme ve Öğretime Hazırlık" alt boyutu puan ortalamaları arasındaki farklılığın hangi gruplardan kaynaklandığını tespit etmek için yapılan Dunnet $C$ testi sonucuna göre, 1 . Sınıfı okutan öğretmenlerin "öğretme ve öğretime hazırlık" puanlarının $(\bar{x}=3,67 \mathrm{~s}=, 57), 2$. Sinıf $(\bar{x}=3,20 \mathrm{~s}=, 73)$ ve 3. sinıf $(\bar{x}=3,30 \mathrm{~s}=, 75)$ okutan öğretmenlerin puanlarından daha yüksek olduğu görülmüştür. Benzer şekilde 4. Sınıfı okutan öğretmenlerin de "öğretme ve öğretime hazırlık" puanlarının $(\bar{x}=3,60 \mathrm{~s}=, 59)$, 2. Sinıf $(\bar{x}=3,20 \mathrm{~s}=, 73)$ ve 3 . sinıf $(\bar{x}=3,30 \mathrm{~s}=, 75)$ okutan öğretmenlerin puanlarından daha yüksek olduğu görülmüştür.

"Ölçme ve Değerlendirme" alt boyutu puan ortalamaları arasındaki farklılı̆̆ın hangi gruplardan kaynaklandığını tespit etmek için yapılan Dunnet $C$ testi sonucuna göre, 3. Sınıfı okutan öğretmenlerin "ölçme ve değerlendirme" puanlarının $(\bar{x}=3,30 s=, 79)$, 1. Sinıf $(\bar{x}=2,76 \mathrm{~s}=, 88)$ ve 2 . sınıf $(\bar{x}=2,98 \mathrm{~s}=, 93)$ okutan öğretmenlerin puanlarından daha yüksek olduğu görülmüştür. Benzer şekilde 4. sınıfı okutan öğretmenlerin "ölçme ve değerlendirme" puanlarının $(\bar{x}=3,73 \mathrm{~s}=, 51), 1$. $\operatorname{sinıf}(\bar{x}=2,76$ $\mathrm{s}=, 88)$, 2.sınıf $(\bar{x}=2,98 \mathrm{~s}=, 93)$ ve 3.Sinıf $(\bar{x}=3,30 \mathrm{~s}=, 79)$ okutan öğretmenlerin puanlarından daha yüksek olduğu görülmüștür.

"Sosyal Etkinlikler ve Rehberlik" alt boyutu puanları ortalamaları arasındaki farklılığın hangi gruplardan kaynaklandığını tespit etmek için yapılan LSD testi sonucuna göre, 4. Sınıfı okutan öğretmenlerin "sosyal etkinlikler ve rehberlik" puanlarının $(\bar{x}=2,80 \mathrm{~s}=, 73), 1$. $\sin \mathrm{f}(\bar{x}=2,44 \mathrm{~s}=, 78), 2$. sinıf $(\bar{x}=2,46 \mathrm{~s}=, 86)$ ve 3 . sinıf $(\bar{x}=2,53 \mathrm{~s}=, 79)$ okutan öğretmenlerin puanlarından daha yüksek olduğu görülmüştür.

"Veli İşbirliği" alt boyutu puan ortalamaları arasındaki farklılığın hangi gruplardan kaynaklandığını tespit etmek için yapılan Dunnet $C$ testi sonucuna göre, 1 . Sinıfı okutan öğretmenlerin "veli işbirliği" puanlarının $(\bar{x}=3,98 \mathrm{~s}=, 83)$, 2. Sınıf $(\bar{x}=3,19 \mathrm{~s}=, 87), 3$. sınıf $(\bar{x}=3,20$ $s=, 72)$ ve 4. sınıfi $(\bar{x}=3,04 s=, 91)$ okutan öğretmenlerin puanlarından daha yüksek olduğu görülmüştür.

"Genel zaman kullanımı" alt boyutu puan ortalamaları arasındaki farklılığın hangi gruplardan kaynaklandığını tespit etmek için yapılan Dunnet $C$ testi sonucuna göre, 4. sinıfı okutan öğretmenlerin "genel zaman kullanımı" puanlarının $(\bar{x}=3,24 \mathrm{~s}=, 53), 2$.Sinıfı $(\bar{x}=2,98, \mathrm{~s}=, 71)$ okutan öğretmenlerin puanlarından daha yüksek olduğu görülmüştür. 
Tablo 8. Mezun Olunan Kurum Değişkenine Göre Mesleki Görevlere Yönelik Zaman Kullanımı Düzeyi Puanları ve Varyans Analizi Sonuçları

\begin{tabular}{|c|c|c|c|c|c|c|c|}
\hline Zaman Kullanımı & $\begin{array}{c}\text { Mezun Olunan } \\
\text { Kurum }\end{array}$ & $\mathrm{n}$ & $\bar{x}$ & $\mathrm{~s}$ & $\mathrm{~F}$ & $\mathrm{p}$ & Fark-Grup \\
\hline \multirow{4}{*}{$\begin{array}{l}\text { Öğretme ve } \\
\text { Öğretime } \\
\text { Hazırllk }\end{array}$} & 1. Eğitim Fakültesi & 230 & 3,48 &, 72 & \multirow{4}{*}{870} & \multirow{4}{*}{,456 } & \multirow{4}{*}{ - } \\
\hline & 2. Eğitim Önlisans & 79 & 3,38 & 63 & & & \\
\hline & 3. Eğitim Enstitüsü & 34 & 3,31 & 68 & & & \\
\hline & 4. Eğitim Fakültesi Dışı & 71 & 3,40 &, 69 & & & \\
\hline \multirow{4}{*}{$\begin{array}{l}\text { Ölçme ve } \\
\text { Değerlendirme }\end{array}$} & 1. Eğitim Fakültesi & 230 & 3,27 &, 87 & \multirow{4}{*}{3,966} & \multirow{4}{*}{,008* } & \multirow{4}{*}{$4-1,4-2,4-3$} \\
\hline & 2. Ĕ̆itim Önlisans & 79 & 3,21 & ,80 & & & \\
\hline & 3. Eğitim Enstitüsü & 34 & 3,24 &, 79 & & & \\
\hline & 4. Eğitim Fakültesi Dışı & 71 & 2,87 & ,93 & & & \\
\hline \multirow{4}{*}{ Mesleki Gelişim } & 1. Eğitim Fakültesi & 230 & 3,08 &, 79 & \multirow{4}{*}{18,741} & \multirow{4}{*}{, $000^{*}$} & \multirow{4}{*}{$4-1,4-2,4-3$} \\
\hline & 2. Ĕ̆itim Önlisans & 79 & 2,93 &, 70 & & & \\
\hline & 3. Eğitim Enstitüsü & 34 & 2,92 & 83 & & & \\
\hline & 4. Eğitim Fakültesi Dışı & 71 & 2,29 & ,86 & & & \\
\hline \multirow{4}{*}{$\begin{array}{l}\text { Sosyal } \\
\text { Etkinlikler ve } \\
\text { Rehberlik }\end{array}$} & 1. Eğitim Fakültesi & 230 & 2,61 & ,83 & \multirow{4}{*}{4,494} & \multirow{4}{*}{, $004 *$} & \multirow{4}{*}{$4-1,4-2,4-3$} \\
\hline & 2. Eğitim Önlisans & 79 & 2,62 &, 76 & & & \\
\hline & 3. Eğitim Enstitüsü & 34 & 2,67 &, 73 & & & \\
\hline & 4. Eğitim Fakültesi Dıșı & 71 & 2,24 &, 74 & & & \\
\hline \multirow{4}{*}{ Veli İşbirliği } & 1. Eğitim Fakültesi & 230 & 3,41 & 87 & \multirow{4}{*}{2,995} & \multirow{4}{*}{, $031^{*}$} & \multirow{4}{*}{$4-1,4-2$} \\
\hline & 2. Ĕ̆itim Önlisans & 79 & 3,48 & 89 & & & \\
\hline & 3. Eğitim Enstitüsü & 34 & 3,12 & ,67 & & & \\
\hline & 4. Eğitim Fakültesi Dışı & 71 & 3,14 & 1,04 & & & \\
\hline \multirow{4}{*}{$\begin{array}{l}\text { Kurul, Komisyon } \\
\text { ve Toplantılar }\end{array}$} & 1. Eğitim Fakültesi & 230 & 2,84 &, 82 & \multirow{4}{*}{9,071} & \multirow{4}{*}{, $000^{*}$} & \multirow{4}{*}{$\begin{array}{l}4-1,4-2, \\
4-3\end{array}$} \\
\hline & 2. Eğitim Önlisans & 79 & 2,84 &, 80 & & & \\
\hline & 3. Eğitim Enstitüsü & 34 & 2,76 & ,80 & & & \\
\hline & 4. Eğitim Fakültesi Dıșı & 71 & 2,29 &, 78 & & & \\
\hline \multirow{4}{*}{$\begin{array}{l}\text { E- Okul İşlemleri } \\
\text { ve diğer }\end{array}$} & 1. Eğitim Fakültesi & 230 & 3,49 & ,85 & \multirow{4}{*}{4,284} & \multirow{4}{*}{, $005^{*}$} & \multirow{4}{*}{$4-1$} \\
\hline & 2. Eğitim Önlisans & 79 & 3,29 &, 84 & & & \\
\hline & 3. Eğitim Enstitüsü & 34 & 3,19 & ,81 & & & \\
\hline & 4. Eğitim Fakültesi Dışı & 71 & 3,11 & ,97 & & & \\
\hline \multirow{4}{*}{$\begin{array}{l}\text { Genel Zaman } \\
\text { Kullanımı }\end{array}$} & 1. Eğitim Fakültesi & 230 & 3,19 & ,62 & & & \\
\hline & 2. Eğitim Önlisans & 79 & 3,13 &, 58 & 7,128 & $000^{*}$ & $4-1,4-2$ \\
\hline & 3. Eğitim Enstitüsü & 34 & 3,05 &, 64 & & & \\
\hline & 4. Eğitim Fakültesi Dışı & 71 & 2,81 &, 59 & & & \\
\hline
\end{tabular}


Tablo 8 incelendiğinde öğretmenlerin mezun olunan kurum değișkenine göre mesleki görevlerine yönelik zaman kullanımı ölçeğinden almış oldukları puan ortalamaları arasındaki farkın anlamlılığını test etmek için yapılan varyans analizi sonucunda, "Öğretme ve Öğretime Hazırlık $(\mathrm{F}=, 870, \mathrm{p}>0.05)$ " alt boyutu dışında, diğer alt boyutlar ve "Genel Zaman Kullanımı" puanları arasında anlamlı farklılık olduğu görülmüştür. Aşağıda öğretmenlerin mezun oldukları kurum değişkenine göre puan dağılımları ve Anova sonuçları sırasıyla verilmektedir.

Öğretmenlerin mezun olunan kurum değişkenine göre "Ölçme ve Değerlendirme" (F=3,966, $\mathrm{p}<0.05)$, puan ortalamaları arasında anlamlı bir farklılık bulunmuştur. "Ölçme ve Değerlendirme" alt boyutu puan ortalamaları arasındaki farklılığın hangi gruplardan kaynaklandığını tespit etmek için yapılan LSD testi sonucuna göre, eğitim fakültesi dışı bir kurumdan mezun olan öğretmenlerin "Ölçme ve Değerlendirme" puanlarının $(\bar{x}=2,87 \mathrm{~s}=, 93)$,eğitim fakültesi $(\bar{x}=3,27 \mathrm{~s}=, 87)$, eğitim önlisans $(\bar{x}=3,21 \mathrm{~s}=, 80)$ ve eğitim enstitüsü $(\bar{x}=3,24 \mathrm{~s}=, 79)$ mezunu olan öğretmenlerin puanlarından daha düşük olduğu görülmüştür.

Öğretmenlerin mezun olunan kurum değișkenine göre "Mesleki Gelișim" (F=18,741, p<.05) puan ortalamaları arasında anlamlı bir farklılık bulunmuştur. "Mesleki Gelişim" alt boyutu puan ortalamaları arasındaki farklılığın hangi gruplardan kaynaklandığını tespit etmek için yapılan LSD testi sonucuna göre, eğitim fakültesi dıșı bir kurumdan mezun olan öğretmenlerin "Mesleki Gelișim" puanlarının $(\bar{x}=2,29 \mathrm{~s}=, 86)$, eğitim fakültesi $(\bar{x}=3,08 \mathrm{~s}=, 79)$, eğitim önlisans $(\bar{x}=2,93 \mathrm{~s}=, 70)$ ve eğitim enstitüsü $(\bar{x}=2,92 \mathrm{~s}=, 83)$ mezunu olan öğretmenlerin puanlarından daha düşük olduğu görülmüştür.

Öğretmenlerin mezun olunan kurum değişkenine göre "Sosyal Etkinlikler ve Rehberlik" $(\mathrm{F}=4,494, \mathrm{p}<0.05)$ puan ortalamaları arasında anlamlı bir farklılık bulunmuştur. "Sosyal Etkinlikler ve Rehberlik" alt boyutu puan ortalamaları arasındaki farklılığın hangi gruplardan kaynaklandığını tespit etmek için yapılan LSD testi sonucuna göre, eğitim fakültesi dıșı bir kurumdan mezun olan öğretmenlerin "Sosyal Etkinlikler ve Rehberlik" puanlarının $(\bar{x}=2,24 \mathrm{~s}=, 74)$,eğitim fakültesi $(\bar{x}=2,61$ $\mathrm{s}=, 83)$, eğitim önlisans $(\bar{x}=2,62 \mathrm{~s}=, 76)$ ve eğitim enstitüsü $(\bar{x}=2,67 \mathrm{~s}=, 73)$ mezunu olan öğretmenlerin puanlarından daha düşük olduğu görülmüştür.

Öğretmenlerin mezun olunan kurum değişkenine göre "Veli İşbirliği" $(F=2,995, p<0.05)$ puan ortalamaları arasında anlamlı bir farklılık bulunmuştur. "Veli İşbirliği" alt boyutu puan ortalamaları arasındaki farklılığın hangi gruplardan kaynaklandığını tespit etmek için yapılan LSD testi sonucuna göre, eğitim fakültesi dişı bir kurumdan mezun olan öğretmenlerin "Veli İşbirliği" puanlarının $(\bar{x}=3,14 \mathrm{~s}=1,04)$, eğitim fakültesi $(\bar{x}=3,41 \mathrm{~s}=, 87)$ ve eğitim önlisans $(\bar{x}=3,48 \mathrm{~s}=, 89)$ mezunu olan öğretmenlerin puanlarından daha düşük olduğu görülmüştür.

Öğretmenlerin mezun olunan kurum değişkenine göre ,"Kurul, Komisyon ve Toplantılar" $(\mathrm{F}=9,071, \mathrm{p}<0.05)$ puan ortalamaları arasında anlamlı bir farklılık bulunmuştur. "Kurul, Komisyon ve Toplantılar" alt boyutu puan ortalamaları arasındaki farklılığın hangi gruplardan kaynaklandığını tespit etmek için yapılan LSD testi sonucuna göre, eğitim fakültesi dışı bir kurumdan mezun olan öğretmenlerin "Kurul, Komisyon ve Toplantılar" puanlarının $(\bar{x}=2,29 \mathrm{~s}=, 78)$, eğitim fakültesi $(\bar{x}=2,84$ $s=, 82)$, eğitim önlisans ( $\bar{x}=2,84 \mathrm{~s}=, 97)$ ve eğitim enstitüsü $(\bar{x}=2,76 \mathrm{~s}=, 80)$ mezunu olan öğretmenlerin puanlarından daha düşük olduğu görülmüştür.

Öğretmenlerin mezun olunan kurum değişkenine göre "E-okul İşlemleri ve diğer" (F=4,284, $\mathrm{p}<0.05$ ) puan ortalamaları arasında anlamlı bir farklılık bulunmuştur. "E-okul İşlemleri ve Diğer" alt boyutu puan ortalamaları arasındaki farklılığın hangi gruplardan kaynaklandığını tespit etmek için yapılan LSD testi sonucuna göre, eğitim fakültesi dıșı bir kurumdan mezun olan öğretmenlerin "Eokul İșlemleri ve diğer" puanlarının $(\bar{x}=3,11 \mathrm{~s}=, 97)$, eğitim fakültesi $(\bar{x}=3,49 \mathrm{~s}=, 85)$ mezunu olan öğretmenlerin puanlarından daha düşük olduğu görülmüştür.

Öğretmenlerin mezun olunan kuruma göre "Genel Zaman Kullanımı" (F=7,128, p<0.05) puan ortalamaları arasında anlamlı bir farklılık bulunmuştur. "Genel Zaman Kullanımı" alt boyutu puan ortalamaları arasındaki farklılığın hangi gruplardan kaynaklandığını tespit etmek için yapılan yapılan LSD testi sonucuna göre, eğitim fakültesi dışı bir kurumdan mezun olan öğretmenlerin "Genel Zaman Kullanımı" puanlarının $(\bar{x}=2,81 \mathrm{~s}=, 59)$, eğitim fakültesi $(\bar{x}=3,19 \mathrm{~s}=, 62)$ ve eğitim önlisans $(\bar{x}=3,13 s=, 58)$ mezunu olan öğretmenlerin puanlarından daha düșük olduğu görülmüștür. 


\section{TARTIŞMA ve SONUÇ}

Araştırmada öğretmenlerin "Öğretme ve Öğretime Hazırlık" görevine yönelik zaman kullanımlarının fazla olduğu sonucu çıkmıştır. Eğitim ve öğretimin etkin ve verimli olabilmesi planlamaya gereken önemin verilmesi ve öğretmenlerin derse hazırlıklı girmeleri ile sağlanabilir. Nitekim derslere hazırlıklı girmek hem eğitsel açıdan gerekli hem de yasal yönden zorunludur (Küçükahmet, 2008, s.150). Öğretme ve öğretime hazırlık görevi alt boyutuna yönelik öğretmenlerin fazla zaman ayırması, öğretmenlerin planlama ve hazırlığı önemsediğini göstermektedir ki bu durum öğretimin verimliliği açısından olumlu bir bulgudur. Öğretmenler "Öğretme ve Öğretime Hazırlık" görevine yönelik faaliyetler arasında en az zamanı "öğretim programlarını inceleme"ye en fazla zamanı ise "materyal ve etkinlik kağıtlarını hazırlama, çoğaltma vb. hazırlıklar" için ayırmaktadırlar. Talim Terbiye Kurulu Başkanlığı tarafından hazırlanan ve öğretmenlere sunulan öğretim programları; öğretmenler arasında bir dersin öğretimine yönelik amaç, içerik, uygulama, ölçme değerlendirme, beceri ve değerler vb. hususlarda ortak bir anlayıș oluşturma ile öğrenci ve öğretmenin öğrenmeöğretme süreci içerisindeki rolünün ortaya konulması açısından oldukça önemlidir (http://ttkb.meb.gov.tr/Eğitim Reformu Girişimi, 2005). Öğretmenlerin öğretim programını incelemeye diğer faaliyetlere göre daha az zaman ayırması, öğretmenler arasında ortak bir anlayış oluşturma açısından olumsuz sonuçlara yol açabilir. Bir başka deyişle öğretmenlerin ulusal olarak belirlenmiş amaç, içerik, öğrenme-öğretme süreçleri ve değerlendirme anlayışından uzaklaşması veya öğretmenlerin kişisel olarak tercih ettikleri amaçlara yönelmesi; öğretim programında ve öğretim anlayışındaki yeniliklerden haberdar olmaması gibi sorunlar ortaya çıkabilir.

Eğitimde ölçme ve değerlendirme öğrencilerin hazır bulunuşluk düzeylerinin ve öğrenme güçlüklerinin neler olduğunun belirlenmesi, öğrencilerin gelişimlerinin izlemesi ve öğrencilerin gelişimlerine yönelik geri bildirimlerde bulunulması vb. birçok husustan dolayı önem arz etmektedir (Algan, 2008; Çelikkaya, 2008). Ölçme ve değerlendirme öğretmenin, öğrencilerin kazanımlara ulaşıp ulaşmadığını tespit etmesi ve gerekli önlemler alması açısından da programın önemli bir öğesidir. Ayrıca yapılan araştırmalar öğretmenlerin oldukça büyük bir kısmının ölçme ve değerlendirme konusunda kendilerini yetersiz ya da eksik bulduklarını göstermiştir (Çakan, 2004; Güven, 2001; Temel, 1991). Bu noktadan hareketle öğretmenlerden ölçme ve değerlendirme için daha fazla zaman ayırması beklenmekte iken araştırmada öğretmenlerin "Ölçme ve Değerlendirme" görevine yönelik zaman kullanımlarının orta düzeyde olduğu sonucu çıkmıştır. Araştırmada öğretmenlerin "Ölçme ve Değerlendirme" görevine yönelik faaliyetler arasında en az zamanı "alternatif değerlendirme formlarını (akran, öz değerlendirme) puanlamaya" en fazla zamanı ise "öğrencilerin ders ve etkinliklerine katılımlarının değerlendirilmesine (ölçeklerin hazırlanması, notlandırma vb.)” ayırdıkları görülmüștür. Gelbal ve Kelecioğlu (2007) yaptıkları araştırmada, öğretmenlerin hiç kullanmadıkları yöntemler arasında ilk sırayı öğrencilerin kendilerini değerlendirmeye yönelik yöntemlerin yer aldığını belirtmektedir. Bu durum öğretmenlerin alternatif değerlendirme formlarını puanlamaya en az zamanı ayırması sonucuyla benzerlik göstermektedir. Bu durum öğretmenlerin çağdaş ölçme ve değerlendirme anlayışını tam olarak benimsemediklerinin bir göstergesi olarak kabul edilebilir.

Öğretmenlerin "Mesleki Gelişim” görevine yönelik zaman kullanımlarının orta düzeyde olduğu sonucu çıkmıștır. Öğretmenler "Mesleki Gelişim" görevine yönelik faaliyetler arasında en az zamanı "alanla ilgili bilimsel ve sanatsal faaliyetlere (seminer, konferans, atölye çalışmaları vb.) katılma" ya en fazla zamanı ise "mesleki gelişim amacıyla meslektaşlarla işbirliği (görüşme, birlikte çalışma vb.) yapma” ya ayırmaktadırlar. Kaçan (2004'ın) öğretmenlerin mesleki gelişime yönelik harcadıkları çabayı incelediği araştırmanın sonuçları bu araştırma ile benzerlik ve farklılıklar içermektedir. Araştırmada öğretmenlerin \%96,8'inin mesleki yayınları takip ettiği, \%87,5'inin eğitimle ilgili bilimsel toplantı ve konferanslara, \%57,0'sinin ise mesleki derneklerin etkinliklerine katıldığı ortaya çıkmıştır. Bu durum bu araştırma ile yani öğretmenlerin bu faaliyetlere ayırdığı zaman ile örtüşmemektedir. Öğretmenlerin \%99,3'ünün meslektaşlarıyla bilgi alışverişinde bulunması ve onları dikkate alması ise bu araştırmanın sonuçları ile örtüşmektedir. Bu araştırmada öğretmenler bilgi ve iletişim teknolojilerindeki gelişmeleri takip etmeye orta düzeyde zaman ayırdıklarını belirtmektedir ancak EARGED, 2011 verilerine göre öğretmenlerin yaklaşık \%60'ı, bilgi ve iletişim 
teknolojisinden yararlanma konusunda genelde başarılı olmadıklarını ifade etmişlerdir (Abazaoğlu, Yıldırım \& Yıldızhan, 2014). Öğretmenlerin alanla ilgili bilimsel ve sanatsal faaliyetlere az zaman ayırması onların alandaki güncel gelişmeleri yeteri kadar takip etmemesi, meslekleriyle ilgili motivasyonlarının düşmesi kısacası eğitim ve öğretimin kalitesi etkileyecek niteliklere yeteri kadar sahip olmamaları anlamına da gelmektedir. Meslektaşlarıyla etkileşim halinde olmaları ise bilgi ve tecrübelerin aktarılması açısından oldukça önemlidir. Bu durum sistematik metotlar ile mesleğe yeni başlayan öğretmenlerden tecrübeli öğretmenlere yeni bilgi ve gelişmelerin aktarılması, tecrübeli öğretmenlerden de yeni başlayan öğretmenlere deneyimlerin aktarılması șeklinde ele alındığında meslektaşlarla işbirliğinin verimli bir süreç olması anlamına da gelmektedir.

Öğretmenlerin "Sosyal Etkinlikler ve Rehberlik" görevine yönelik zaman kullanımlarının az olduğu sonucu çıkmıştır. 1739 sayılı Milli Eğitim Temel Kanununda Türk Milli Eğitim'inin Genel Amaçları incelendiğinde, öğrencilerin beden, zihin, ahlak, ruh ve duygu bakımlarından dengeli ve sağlıklı şekilde gelişmesi amaçlanmıştır (md. 2). Bu amaç okulları sadece akademik anlamda öğretim yapılan bir yer olmaktan çıkarmaktadır ve çocuğun çok yönlü gelişiminin sağlanmasına da hizmet etmesi gerektiğini ortaya koymaktadır. Öğrencilerin bulundukları toplumda öz güvenli ve sağlıklı bir kişilik oluşturup yeteneklerini geliştirebilmesi, ev ve okul ortamında katıldığı sosyal etkinliklerle gerçekleşebilmektedir. Okulların programlarında yer alan çeşitli sportif faaliyetler, tiyatrolar, geziler vb. etkinlikler çocuğun bedensel ve duyuşsal gelişimi açısından yararlı olduğu gibi aynı zamanda çocuğun bir gruba dahil olma, uyum sağlama, işbirliği yapabilme gibi sosyal becerilerini de geliștirir (Aslan \& Cansever, 2007). Bu durum okullardaki öğrenci kulüpleri, toplum hizmeti çalışmaları ve rehberlik çalışmalarını ön plana çıkarmaktadır. Fakat araştırma sonucunda öğretmenlerin sosyal etkinlikler ve rehberlik için az zaman ayırması, çocuğun çok yönlü gelişimine yeteri kadar katkı sağlama çabasının gösterilmediğini ortaya koymaktadır. Araştırmada öğretmenlerin "Sosyal Etkinlikler ve Rehberlik" görevine yönelik faaliyetler arasında en az zamanı "öğrenci kulübü ve toplum hizmetine ilişkin çalışmalara (hazırlıklar, faaliyetleri yapma vb.)", en fazla zamanı ise "öğrenci kulübü (sosyal Kulüp) ve toplum hizmeti planını hazırlama ya ayırdıkları görülmektedir. Tetik(2008), sosyal etkinliklerin, okullarda tam anlamıyla uygulanmadığını, yönetmelik ve formalite gereği öğrenci kulüpleri oluşturulduğunu, seçimler yapıldığını, defter tutulduğunu ve bu konunun önemini kavrayan bir kısım yönetici ve öğretmenlerin çabaları dışında sosyal etkinliklere ilişkin çalışmaların yetersiz kaldığını ifade etmektedir. Nitekim yapılan araştırma sonucunda öğretmenlerin en az zamanı öğrenci kulübü ve toplum hizmetine ilişkin çalışmalara hatta bu çalışmaların planını yapmaya bu çalışmalardan daha fazla zaman ayırması Tetik'in (2008) bu görüşünü destekler niteliktedir. Bu durum eğitim-öğretimin, öğretim odaklı olduğunun da bir göstergesidir.

Araştırmada öğretmenlerin "Veli İşbirliği", görevine yönelik zaman kullanımlarının orta düzeyde olduğu sonucu çıkmıștır. Öğretmenler "Veli İşbirliği" görevine yönelik faaliyetler içinde en fazla zamanı "bireysel veli görüşmeleri (yüz-yüze, telefonla)" ne ayırmaktadırlar. Genç (2005) tarafından yapılan araştırmaya göre öğretmenler, velilerin çocuklarının durumuyla ilgili görüşmeye geldikleri $(\% 88,5)$, ancak bunu ara sıra gerçekleștirdikleri (\%78) ifade edilmektedir. Velilerin ise $\% 92$ 'si sınıf öğretmeniyle görüştügünü ve \%54,5'i ise bir eğitim-öğretim yılında dört ve daha fazla kez sınıf öğretmeniyle görüşme yaptıklarını belirtmektedir. Araştırmada öğretmenlerin "Veli İşbirliği" görevine yönelik faaliyetler arasında en az zamanı "veli ziyaretleri (hazırlıklar, tutanaklar ve diğer işler dahil)" ayırdığı tespit edilmiştir. Nitekim Ceylan ve Akar (2010) tarafından yaplan araştırma öğretmenlerin yalnızca \%28'inin, velilerin ise yalnızca \%27,5'inin "velilere yönelik ev ziyaretleri yapılmalı" düşüncesine katıldıklarını ortaya koymaktadır. Bu durum öğretmen ve velilerin karşılıklı olarak veli ziyaretlerine sıcak bakmadığını göstermektedir. Ceylan ve Akar (2010) tarafından yapılan araştırmanın bulgusu, öğretmenlerin veli ziyaretlerine daha az zaman ayırması sonucuna sebep olan bir unsur olarak görülmektedir.

Öğretmenlerin "Kurul, Komisyon ve Toplantılar" görevine yönelik zaman kullanımlarının orta düzeyde olduğu sonucu çımıştır. Öğretmenler "Kurul, Komisyon ve Toplantılar" görevine yönelik faaliyetler arasında en az zamanı "Okul gelişim yönetim ekibi(OGYE), ekip, birim, kurul ve komisyonlarla işbirliği yapma”ya ayırmaktadırlar. Şahin (2006) yaptığı araștırmada okul gelişim planını çoğunlukla bir iki kişinin hazırladığını ve hem öğretmenlerin hem de idarecilerin okul gelişim yönetim ekiplerinin oluşturulmasında isteksiz olduğunu ve bu sebeple bu ekiplerin çalışmaları 
yapma konusunda isteksiz kişilerden oluştuğunu belirtmektedir. Bu durum öğretmenlerin "Kurul, Komisyon ve Toplantılar" görevini mesleki faaliyet olarak benimsemediklerinin bir göstergesidir.

Öğretmenlerin "E-Okul, İşlemleri ve diğer" görevine yönelik zaman kullanımlarının orta düzeyde olduğu sonucu çıkmıştır. Öğretmenler "E-Okul İşlemleri ve diğer" görevine yönelik faaliyetler arasında en az zamanı "resmi yazıları takip etme ve imzalama" ya en fazla zamanı ise "eOkula öğrenci bilgilerini girme, güncelleme vb." ye ayırmaktadırlar. Akar (2009) tarafından yapılan araştırmada öğretmenlerin e-okul işlemlerini faydalı ve kullanışlı bulduğu sonucu ortaya konulmuştur. Araştırmada öğretmenler e-okul programını zaman kaybı yaşamadan kullanabiliyorum ifadesine ise kararsızım düzeyinde katıldıklarını belirtmişlerdir.

Öğretmenlerin mesleki görevlerine yönelik en fazla zamanı: "Öğretme ve Öğretime Hazırlık" görevi için harcadıkları en az zamanı ise "Sosyal Etkinlikler ve Rehberlik" görevi için harcadıkları ortaya konulmuştur. Öğretmenler mesleki faaliyetler arasında en az zamanı "öğrenci kulübü ve toplum hizmetine ilişkin çalıșmalar (hazırlıklar, faaliyetleri yapma vb.)" en fazla zamanı ise "materyal ve etkinlik kağıtlarını hazırlama, çoğaltma vb. hazırlıklar (BEP olan öğrenciler için yapılan hazırlıklar dahil)" için ayırmaktadır. Draeger (1995) yaptığı araştırmada; öğretmenlerin mesleki görevlerini en fazla zaman ayırılandan en az zaman ayrılana doğru şu şekilde sıralanmaktadır: Öğretimsel planlama, öğrenci çalışmalarını puanlama, mesleki gelişim, öğrenci danışmalıkları, veli iletişimi ve toplantılar. $\mathrm{Bu}$ sıralama bu araştırmanın sonuçları ile benzerlik ve farklılıklar göstermektedir. Her iki araştırmada da öğretmenler en fazla zamanı "Öğretme ve öğretime hazırlık" için ayırmaktadır. Draeger'in (1995) çalışmasında ölçme ve değerlendirme ikinci, mesleki gelişim üçüncü sırada iken bu araştırmada dördüncü ve beşinci sıradadır. Draeger (1995) tarafından yapılan çalışmada veli işbirliği beşinci sırada iken bu araştırmada üçüncü sırada yer almaktadır. Araştırmada dikkat çeken diğer bir husus ise öğretmenlerin "e-okul işlemleri ve diğer" mesleki görevine aslında eğitim-öğretim açısından daha önemli olan ölçme değerlendirme, veli işbirliği vd. görevlerden daha fazla zaman ayırmasidır.

Kadın öğretmenler "Öğretme ve Öğretime Hazırlık", "Ölçme ve Değerlendirme" ve "Veli İşbirliği" görevlerine erkek öğretmenlerden daha fazla zaman ayırmaktadırlar. Benzer şekilde "Genel Zaman Kullanımı" da erkek öğretmenlerden daha fazladır. Thomas (2005)'ın yaptığı araştırmanın sonuçlarında öğretmenlerin mesleki gelişim ve idari görevlere yönelik çalışmalarında cinsiyete göre anlamlı bir farklılık bulmaması bu araştırma ile tutarlık göstermektedir. Thomas (2005)'ın yaptığı araştırmanın sonuçlarında öğretim, hazırlık, değerlendirme ve diğer görevlere yönelik anlamlı bir farklılık bulmaması ise bu araştırma ile tutarlılık göstermemektedir. Benzer şekilde Kaçan (2004) tarafından yapılan araştırmada da öğretmenlerin cinsiyetlerine göre mesleki gelişim için harcadıkları çaba arasında bir farklılığın ortaya çıkması da bu araştırma ile benzerlik göstermektedir.

Mesleğinin ilk 5 yılında bulunan öğretmenler daha deneyimli öğretmenlere göre "Öğretme ve Öğretime Hazırlık" ile "Mesleki Gelişim" görevleri için daha fazla zaman ayırmaktadır. Draeger (1995) tarafından yapılan araştırma sonuçları mesleklerinin ilk yılında olan öğretmenlerin mesleki gelişim için daha az zaman harcadıklarını ortaya koymaktadır ki bu araştırmada ortaya çıkan sonuç ile farklılık göstermektedir. Bu araștırmada mesleki deneyimi 21 yll ve üstü olan öğretmenlerin "mesleki gelişim" puanlarının 11-15 yıl ve 16-20 yıl olanlardan daha fazla olduğu görülmüştür. Bu sonuçla ilişkili olabilecek benzer bir sonuca Kaçan (2004) tarafından yapılan araştırmada rastlanılmıştır. Kaçan (2004) tarafından yapılan araştırmada hizmet yılı 21 yıl ve üzeri olan öğretmenler, diğer öğretmenlere göre mesleki gelişim için daha çok çaba harcamaktadırlar. Öğretmenlerin mesleklerinin ilk beș yılından sonra mesleki gelişime daha az zaman ayırmaları, deneyim kazanmanın öğretmenlerin mesleki gelişime isteklilik gösterme açısından olumsuz etkilediğini göstermektedir. Halbuki öğretmenlerden bunun tersi bir durum beklenmektedir. Bilgileri eskidikçe güncel gelişmeleri takip etmek için mesleki gelişme daha fazla zaman ayırmaları gerekmektedir.

Öğrenci sayısı 1-10 arasında olan öğretmenlerin “Genel Zaman Kullanımı” öğrenci sayısı daha fazla olan öğretmenlere göre daha azdır. Öğrenci sayısı 1-10 arasında olan öğretmenler, materyal hazırlama, fotokopi, sınav kağıtlarını okuma, daha az veli ile görüşme gibi avantajlara sahip olabileceğinden dolayı öğrenci sayısı daha fazla olan öğretmenlere göre mesleki görevlerine daha az zaman ayırdıkları söylenebilir. Nitekim Atkins, Carter ve Nichol (2002) yaptıkları araştırmada sınıf büyüklüğü azaldıkça öğretmenlerin iş yükünün azaldığı sonucuna ulaşmışlardır. 
1. sınıfları ve 4. sınıfları okutan öğretmenler, 2. sınıf ve 3. sınıfı okutan öğretmenlere göre "Öğretme ve Öğretime Hazırlık" için daha fazla zaman ayırmaktadır. 1. sinıfları okutan öğretmenler diğer kademeleri okutan öğretmenlere göre "Veli İşbirliği" için daha fazla zaman ayırmaktadır. Araştırma sonucunda birinci sınıfı okutan öğretmenlerin diğer sınıfı okutan öğretmenlere göre veli işbirliğine daha fazla zaman ayırması olumlu bir bulgudur. Nitekim öğrencilerin okulda başarıya ulaşabilmesi için, okulda yapılan şeylerin evde anne-babalar tarafından desteklenmesi gerekir. Okul ve aile eğitim konusunda farklı beklentiler içerisinde olabilir fakat bu iki farklı kurumun çocukların eğitimleri konusunda ortak bir anlayış oluşturması gereklidir. Özellikle formal eğitimin başlangıcı olan ilkokul birinci sınıflar için bu durum çok daha kritiktir, çünkü en temel çalışma ve öğrenme becerileri bu yılda oluşturulmaktadır (Şimşek \& Tanaydın, 2001). Dolayısıyla hem öğretmenin veli ile hem de velinin öğretmen ile diğer sınıf kademlerine göre daha fazla iletişim kurması gerekmektedir.

Araştırmada eğitim fakültesi dışı bir kurumdan mezun olan öğretmenlerin özellikle eğitim fakültesi mezunlarına göre "Öğretme ve Öğretime Hazırlık" görevi dışında bütün boyutlarda zaman kullanımlarının daha az olduğu görülmektedir. Bu durum eğitim fakültesi dıșı bir kurumdan mezun olan öğretmenlerin, öğretmenlik mesleğini sadece konu alanını öğretmek olarak algılamasından kaynaklanabilir.

Sonuç olarak öğretmenlerin mesleki görevlerine yönelik ders dıșı zaman kullanımlarının yüksek olmadığı ve çeșitli değişkenlere göre de zaman kullanımlarının farklılaștığı görülmüştür. Öğretmenlerin zaman kullanımlarının çeşitli değişkenlere göre farklılaşması, okul zaman çizelgelerinin hazırlanmasında sadece öğrenci ve konu alanının ihtiyaçları değil, öğretmenlerin de zaman konusundaki ihtiyaçları dikkate alınarak hazırlanması gerekliliğini ortaya çıkarmıştır. Örneğin; öğretmenler için okul zaman çizelgesine eklenebilecek veli görüşme saati 1. sınıfı okutan öğretmenler için daha uzun olabilir. Ayrıca öğretmenlerin görevlerini gerçekleştirmek için zamanı ne derecede etkin kullandıklarının belirlenmesine ve zaman kullanımına yönelik algıları ile gerçek zaman kullanımı arasındaki farklılığa yol açan psikolojik veya diğer sebeplerin belirlenmesine yönelik araştırmalar yapılabilir.

\section{KAYNAKÇA}

Abazaoğlu, İ., Yıldırım O., \& Yıldızhan, Y. (2014). Türkiye' nin öğretmen profili. Turkish Studies International Periodical For The Languages, Literature and History of Turkish or Turkic, 9(2), 1-20.

Akar, H. (2009). E-okul uygulamasının başarısına yönelik ilköğretim okulu öğretmen ve idarecilerinin görüşleri. Yüksek Lisans Tezi. Gaziosmanpaşa Üniversitesi Sosyal Bilimler Enstitüsü, Tokat.

Algan, S. (2008). İlköğretim 6. ve 7. sınıf sosyal bilgiler dersi ögrretim programının ölçme ve değerlendirme öğesinin ögrretmen görüşleri açısından incelenmesi. Yüksek Lisans Tezi, Çukurova Üniversitesi Sosyal Bilimler Enstitüsü, Adana.

Aslan, N., \& Cansever A., B. (2007). Okuldaki sosyal etkinliklere katılımda ebeveyn- çocuk etkileşimi (kültürlerarası bir karşılaştırma). Ege Eğitim Dergisi, (8)1, 113-131.

Atkins,J., Carter, D., \& Nichol, M. (2002). The impact of class size on teacher workload.(Report). Retrieved from http://www.nut.org.uk/files/active/0/class-size-report4.pdf

Campbell, R. J., \& Neill, S. R. St. J. (1994a). Primary teachers at work. New York, NY: Routledge.

Ceylan, M., \& Akar, B. (2010). Ortaöğretimde okul-aile işbirliği ile ilgili öğretmen ve veli görüşlerinin incelenmesi (Karacasu Lisesi örneği). Çankırı Karatekin Üniversitesi Sosyal Bilimler Enstitüsü Dergisi 2,43-64

Çakan, M. (2004). Öğretmenlerin ölçme-değerlendirme uygulamaları ve yeterlik düzeyleri: ilk ve ortaöğretim. Ankara Üniversitesi Ĕ̆itim Bilimleri Fakültesi Dergisi, (37)2, 99-114

Çelikkaya, T. (2008). Yapılandırmacı yaklaşımın sosyal bilgiler öğretiminde başarı, tutum ve kalıcılığa etkisi (5.sınıf örneği).Doktora Tezi, Atatürk Üniversitesi Sosyal Bilimler Enstitüsü, Erzurum 
Draeger, B. (1995). A descriptive study of teacher time usage and allocation in Fairfax County public schools,Virginia. Doctoral Dissertation, Virginia Polytechnic Institute and State University, Virginia

Eğitim Araştırma Geliştirme Dairesi Başkalığı (1993). Öğretim Yükünün Analizi. http://www.meb.gov.tr/earged/earged/ogretim_yuku_analizi.pdf sayfasından erişilmiştir.

Eğitim Reformu Girişimi (2005). Yeni öğretim programlarını inceleme ve değerlendirme raporu. http://www.erg.sabanciuniv.edu/docs/mufredat_raporu.doc sayfasından erişilmiştir.

Eurydice (2008). Avrupa'daki Öğretmenlerin Sorumluluk ve Özerklik Düzeyleri. http://eacea.ec.europa.eu/education/eurydice/documents/thematic_reports/094TR.pdf. sayfasından erişilmiştir.

Field, A. (2009). Discovering statistics using spss. London: Sage

Finnish National Board of Education (2013). Teachers in Finland. http://www.oph.fi/english/publications/brochures sayfasından erişilmiștir.

Garrick, A.J., Mak, A., Cathcart, S., Winwood, P.C., Bakker, A.B. Lushington, K. (2017). Non-work time activities predicting teachers' work-related fatigue and engagement: An effort-recovery approach. Australian Psychologist 52,3 DOI: 10.1111/ap.12290

Gelbal S., \& Kelecioğlu H. (2007). Öğretmenlerin ölçme ve değerlendirme yöntemleri hakkındaki yeterlik algıları ve karşılaştıkları sorunlar. Hacettepe Üniversitesi Eğitim Fakültesi Dergisi, 33, 135-145.

Genç, S. Z. (2005). İlköğretim 1. kademedeki okul-aile işbirliği ile ilgili öğretmen ve veli görüşleri. Türk Eğitim Bilimleri Dergisi, 3(2), 227-243.

Gibson, S. Oliver L. \& Dennison M.(2015) Workload Challenge: Analysis of teacher consultation responses

Research report. Department for Education.

Güven, S. (2001, Haziran). Sinıf öğretmenlerinin ölçme ve değerlendirmede kullandıkları yöntem ve tekniklerin belirlenmesi. 10. Ulusal Eğitim Bilimleri Kongresinde sunulmuş bildiri, Abant İzzet Baysal Üniversitesi, Bolu.

Gwambombo, I. (2013). The effect of teachers' workload on students' academic performance in community secondary schools a study of mbeya city. Master Thesis. Administration, Planning and Policy Studies (MED. APPS) of the Open University of Tanzania.

Higton, J., Leonardi, S., Richards N., Choudhoury, A., Sofroniou N. \& Owen D.(2017). Teacher workload

Survey 2016 research report. ISBN 978-1-78105-689-9, DFE-RR633 https://www.gov.uk/government/publications/teacher-workload-survey-2016 sayfasindan erişilmiştir.

Hilsum, S., \& Cane, B. S. (1971). The teacher's day, Windsor, National Foundation for Educational Research.

Jha J., Minni P. \& N. Ghatak (2016).Working Conditions of Teachers: State Report for Karnataka. National University of Educational Planning and Administration (NUEPA) ,New Delhi

Kaçan, G. (2004). Sınıf öğretmenlerinin mesleki gelişime ilişkin isteklilik düzeyleri. Osmangazi Üniversitesi Sosyal Bilimler Dergisi, 5 (1),57-66

Kalaycı, Ș. (2006). SPSS uygulamalı çok değişkenli istatistik teknikleri. Ankara, Asil

Karasar, N. (1998). Bilimsel araştırma yöntemi. Ankara, Nobel

Küçükahmet, L. (2008). Öğretimde planlama ve değerlendirme. Ankara: Nobel

OECD (2012). "How much time do teachers spend teaching?" in education at a glance 2012: Highlights, OECD Publishing.

Şahin, İ. (2006). İlkögretim müfredat laboratuvar okullarının okul gelistirme süreci açısından incelenmesi. Doktora Tezi, Dokuz Eylül Üniversitesi Eğitim Bilimleri Enstitüsü, İzmir

Şimşek, H. \& Tanaydın D. (2001). Öğretmen veli Katılımı: Öğretmen,-Veli-Psikolojik Danışma üçgeni, İlköğretim Online 1(1),12-16. 23 Ocak 2016 tarihinde http://ilkogretimonline.org.tr/vol1say1/v01s01b.pdf sayfasından erişilmiștir. 
Talim ve Terbiye Kurulu Başkanlığı (2016). Öğretim programları. http://ttkb.meb.gov.tr/ adresinden erişilmiştir.

TALIS (2008). The experience of new teachers results from talis 2008. http://www.oecd.org/edu/school/49846877.pdf sayfasından erişilmiştir.

Temel, A. (1991). Ortaöğretimde Ölçme ve Değerlendirme Sorunları. Yaşadıkça Eğitim Dergisi, 18, 23-27.

Tetik, V. (2008). Genel liselerde sosyal etkinliklerin uygulanmasında okul yöneticilerinin etkililiği. Yüksek Lisans Tezi, Yeditepe Üniversitesi Sosyal Bilimler Enstitüsü, İstanbul.

Thomas, B. (2005). Teachers' time on task. Doctoral dissertation, Capella University,USA

Wolf, M. A. (2002, August). Teacher time: A study of time and tasks required to complete job related work. Doctoral dissertation. University of Virginia, USA. 